\title{
Social Transformations and Resilience
}

\section{The Example of Continental Animal Style III and the Tassilo-Liutpirc Chalice}

\author{
Alexandra Pesch ()
}

The amazing goblet known as the 'Tassilo Liutpirc Chalice' is one of the most significant archaeological objects from the eighth century AD. Surprisingly, the animal figures that adorn it have close parallels with the creatures of the Germanic animal styles from the fifth century onwards. This paper explores the deeply-rooted traditions behind this continuity, and the social, cultural and political mechanisms that sustained it, transcending the boundaries of epochs and religions. It is argued that a supra-regional network of workshops was the driving force in the development of this sophisticated imagery.

Keywords: Germanic Animal Styles, long-distance communication, social impact of visual art, Germanic Iron Age/Anglo-Saxon period, network of goldsmith workshops, Insular art

Zentrum für Baltische und Skandinavische Archäologie, Schloss Gottorf alexandra.pesch@zbsa.eu 
Nothing is unchanging in the world of humans. Both present and past societies experience constant processes of change and development. Increasingly, modern archaeology investigates the people who experienced, shaped and survived such transformations, as well as the mechanisms that triggered change in society. Despite these fluctuations, stable elements that represent an undercurrent of continuity across the centuries can sometimes be traced in the find material. The example of Germanic Animal styles allows cultural integrity and resilience to be recognized, as well as progress and conversion in an international perspective.

In Northern Europe, animal art styles are a fascinating expression of the pre-Christian era in the first millennium AD. The material culture of these periods features many images based on or incorporating representations of real or fantastic animal bodies or body parts. These appear to be standardized in terms of overall motifs, organizational principles and elements of detail. The images were part of a common way of thinking, and essentially formed a language of images. They were designed to be universally recognized and understood. The depictions carry messages from times and societies in which writing was barely known. The first to classify these styles was Swedish researcher Bernhard Salin in his landmark book Die Altgermanische Thierornamentik (published in 1904; for general information, see Haseloff I98г; Karlsson I983; Høilund Nielsen I998; Høilund Nielsen \& Kristoffersen 2002; Pesch 20I2). He defined and described three art styles, of which the first two, Animal Styles I and II, dominated the entire visual culture in the North from the fifth to the seventh century. The third style, most prevalent in the late seventh and eighth centuries, had a tendency to incorporate local traits and therefore was a more diverse phenomenon. As a result, it was little referred to later (see Capelle I998:368369; Ament \& Wilson 2005:594-595), especially after the subdivision of Styles II and III into the so-called 'Vendel Styles' (Arwidsson I942:I8-2I; Ørsnes I966). On the other hand, animal figures on Continental objects of the eighth and ninth centuries are often identified as executed in 'Style III' (Bakka I983; Bierbrauer, V. 200I), giving the impression that this style is a direct descendant of the older Germanic styles. Contrary to the earlier pagan art, however, the objects on which this 'style' occurs often belong to Christian liturgical contexts, and were manufactured in monastic workshops. As a consequence, this style's origin in, and its connection to, the older pagan animal art styles has repeatedly been challenged by researchers. What might the social reality and cultural background of phenomena such as these have been?

The 'Continental Animal Style' or 'Style III of the Carolingian Period' is also called 'Tassilo Chalice Style'. This name derives from the TassiloLiutpirc Chalice, a large, magnificently decorated silver goblet (figure I), 


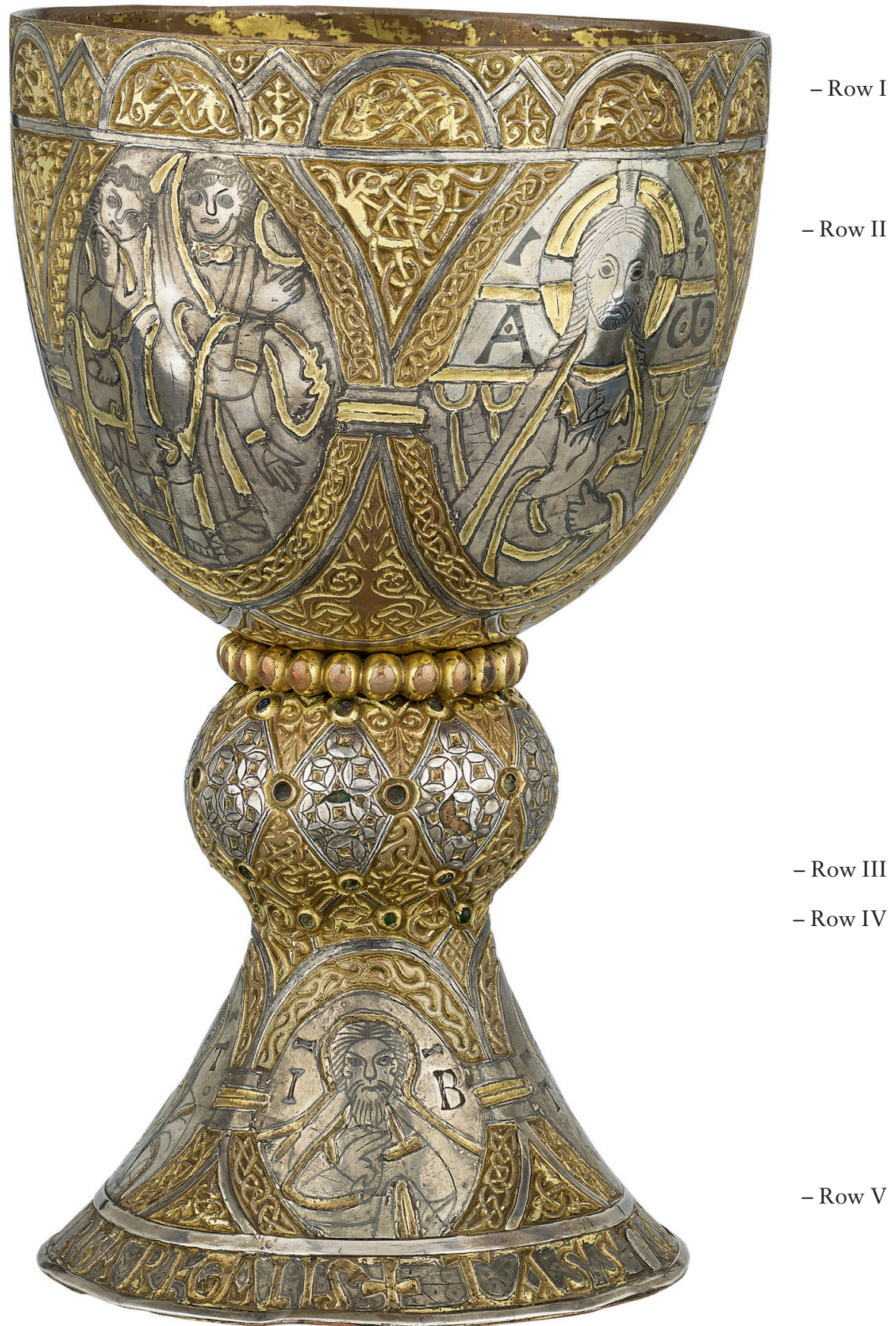

Figure I. The Tassilo-Liutpirc Chalice, later eighth century; Kremsmünster Abbey, Upper Austria. Photograph: Volker Iserhard, Römisch-Germanisches Zentralmuseum (RGZM), Mainz, Germany, reproduced with kind permission. 
which is one of the most significant archaeological objects from the eighth century AD (see Bauerreiß I932; Haseloff I95 I, I977; Wamers 2005, 20I3, 20I5; Wamers [ed.] 20I9; Wintz 20I4). An inscription circling the chalice's foot identifies two named individuals - Tassilo and Liutpirc - as sponsors of the chalice. Liutpirc (or Liudbirc) is known from other sources as the daughter of the Lombard king Desiderius and the wife of Tassilo III, the powerful Bavarian duke of the Agilolfing dynasty (c. 74I-796). Learning and the visual arts flourished in Bavaria during their rule in the second half of the eighth century. Tassilo was a generous supporter of the church and a founder of monasteries, and in 777 he donated the chalice to Kremsmünster Abbey in Upper Austria. Later, however, Tassilo came into conflict with his cousin, the Frankish king Charles (later to be the Emperor Charlemagne), who had him arrested, tried and deposed around 788 so he could seize $\mathrm{Ba}-$ varia for himself (Becher 20I9).

On its outer surface, the chalice displays extraordinary figural images, among them a large number of animals. The first to examine them in detail was Günther Haseloff. In his monograph Der Tassilokelch (I95I), he describes many of the animals and provides several drawings. However, the complete photographic and graphic documentation of all of the animal figures on the chalice, as well as of its other elements, was achieved only recently, when a research project conducted by specialists from the RömischGermanisches Zentralmuseum extensively studied the famous chalice and comparable works of art, and published its results in an impressive compilation of articles (see Wamers [ed.] 20I9; Wamers 2019c). ${ }^{1}$

It is a striking fact to note that different traditions of visual art come together in one liturgical object, making the chalice a prime example of 'the contrast between the traditional, abstract ornamentation and a visual art struggling for new ways of expression' (Haseloff I95I:I2; Wamers 2019a:390-39I). The most eye-catching features are the five silver medallions with human busts on the bowl (cuppa), one of which shows Christ with a cross nimbus; four similar medallions are also on the goblet's foot. These all have relatives in contemporaneous Italian figural art (Wamers 2019a:388-390, 20I9b:459-46I), while the interlace and floral patterns of the borders surrounding the medallions have close parallels in objects of Mediterranean and Insular origin. Several other pictorial elements fill the spandrels and decorate all other spaces on the surface of the bowl, the node and the foot, with many of them taken from flora and fauna, albeit in highly stylized forms.

I As part of this project, the animal figures of the chalice were also re-examined (Pesch 20I9). That work also forms the basis for this text, which aims to make the results, along with new ideas, accessible to an international audience. 
There are 29 gilded animal figures (figures $2-5$ ) on the chalice, interlaced with their own limbs and tails. Compared to the other elements of the pictorial programme of the chalice, these animals appear foreign and exotic. Yet, they appear to have ancestry in the northern animal styles.

It is these surprising similarities that this paper seeks to analyse. The aim is to shed light on a possible continuity of design elements and art concepts over many centuries and across wide regions of Europe. Furthermore, the mechanisms of this unexpected continuity will be considered, along with their social, cultural and ideological causes. To this end, the animals and their design are examined in close detail.

\section{Chalice creatures}

All of the animals displayed on the chalice are quadrupeds (figures 2-5). They occupy spaces of different shapes within the architectonical framework (Wamers 20I9b), filling them as completely as possible with their bodies, limbs, tails and associated ribbons, thus taking on the geometrical shape of their respective spaces. They are arranged in rows which include other elements too.

In row I, ten semi-oval animals appear as elements of the frieze on the сирpa's rim (figure 2). Almost all of them feature a small, often roundish head (exceptions are nos I: 7.8, which have larger heads as well as pointed ears) with one almond-shaped or oval eye and a gaping mouth. The head merges into a sigmoid 'ribbon-body' (Germ. 'Bandleib') and is turned backwards, looking over its own back. An exception is one beast (no. I: 4), whose lower jaw is turned to the outside, looking forwards and up. It is common for only three of the limbs of the quadrupeds to be shown, with one of the forelegs not visible. The hind legs are drawn either parallel to each other or splayed (exceptions: I: 7.8, with four limbs each). The single foreleg reaches forwards and upwards, with the forefoot lying beneath or near the head. Most of the animals of row I exhibit a shoulder spiral (exceptions: I: 7.8). The paw-like feet of all the beasts appear to have two toes each. The long tails coil in loops or knots (I: 5), branching into two individual ribbons (I: I.4.5.7), and/or join the long tongues emerging from the heads of the animals (I: 7.8). In two cases, the ends of the tails are trefoil-shaped (I: 4.9). Three basic constellations can be distinguished: four animals form one group (I: I.2.3.6) and are mirrored by four others (I: 4.5.9.IO), and two beasts (I: 7.8) differ from the rest by the design of the head, which has ears and a tongue, and by the presence of a second foreleg. At the intersections, the ribbons of body, limbs, tails and tongues mostly run above and below each other in a regular way, but in some instances the contour lines marking a limb that 

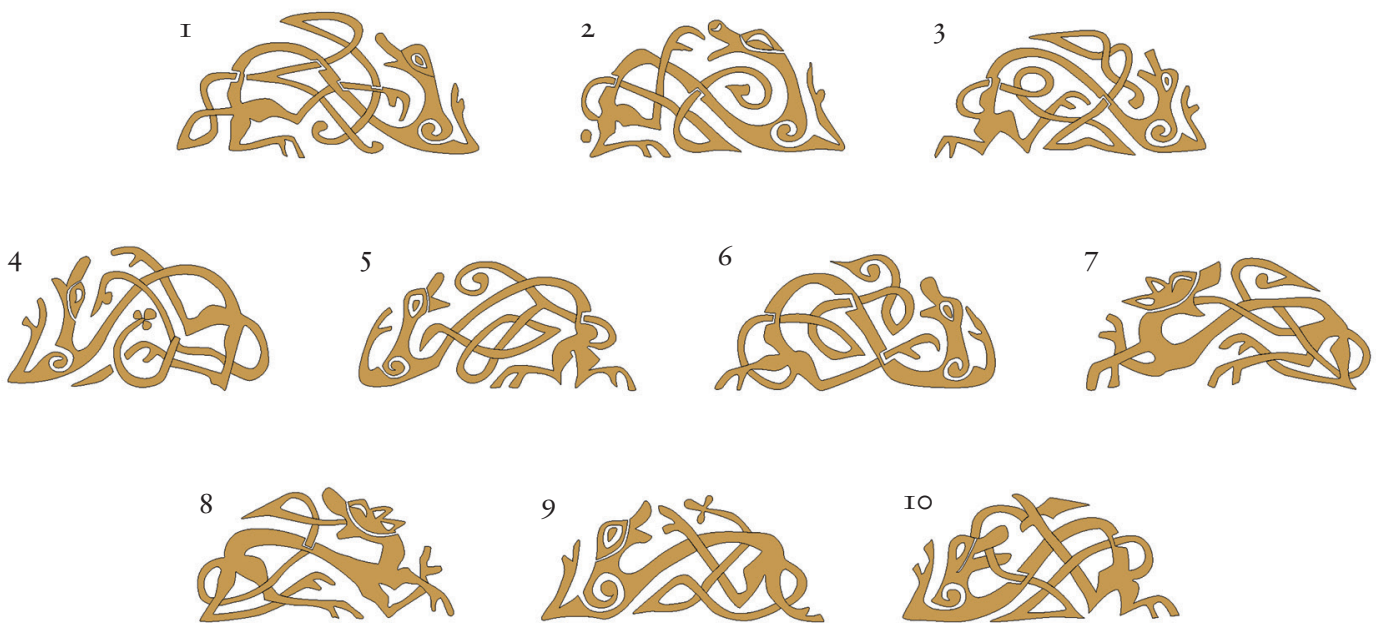

Figure 2. Tassilo-Liutpirc Chalice: the quadrupeds in row I, height: $c .1 .5 \mathrm{~cm}$ each. Drawings: Vera Kassühlke, RGZM. After Pesch 20I9:324.
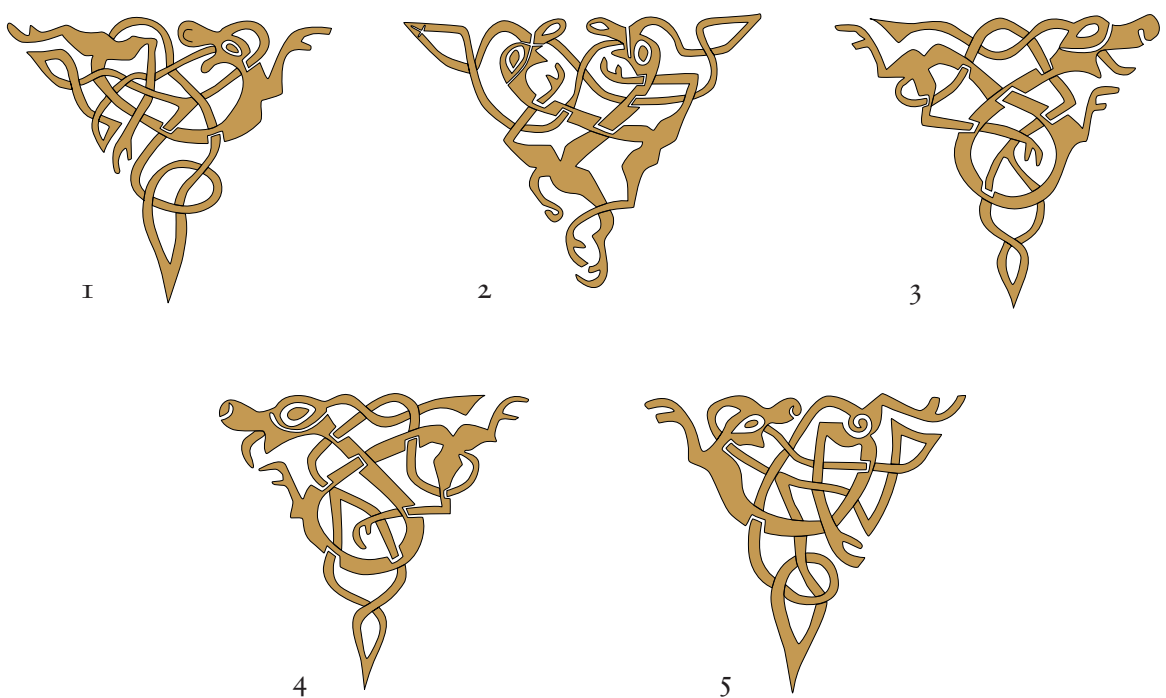

Figure 3. Tassilo-Liutpirc Chalice: the quadrupeds in row II, height: $c .3 .7 \mathrm{~cm}$ each. Drawings: Vera Kassühlke, RGZM. After Pesch 2019:324.

should overlay another limb end abruptly in the middle of the other limb, giving the impression that the first limb pierces the other (I: I.2.3.5.6.8.Io). This detail has been described as 'permeation' and is considered an Insular Anglo-Saxon style element (Haseloff I95 I:48-49).

Row II occupies the upper spandrels between the cuppa's main medallions and consists of five triangular motifs with one - or in one case, two - 

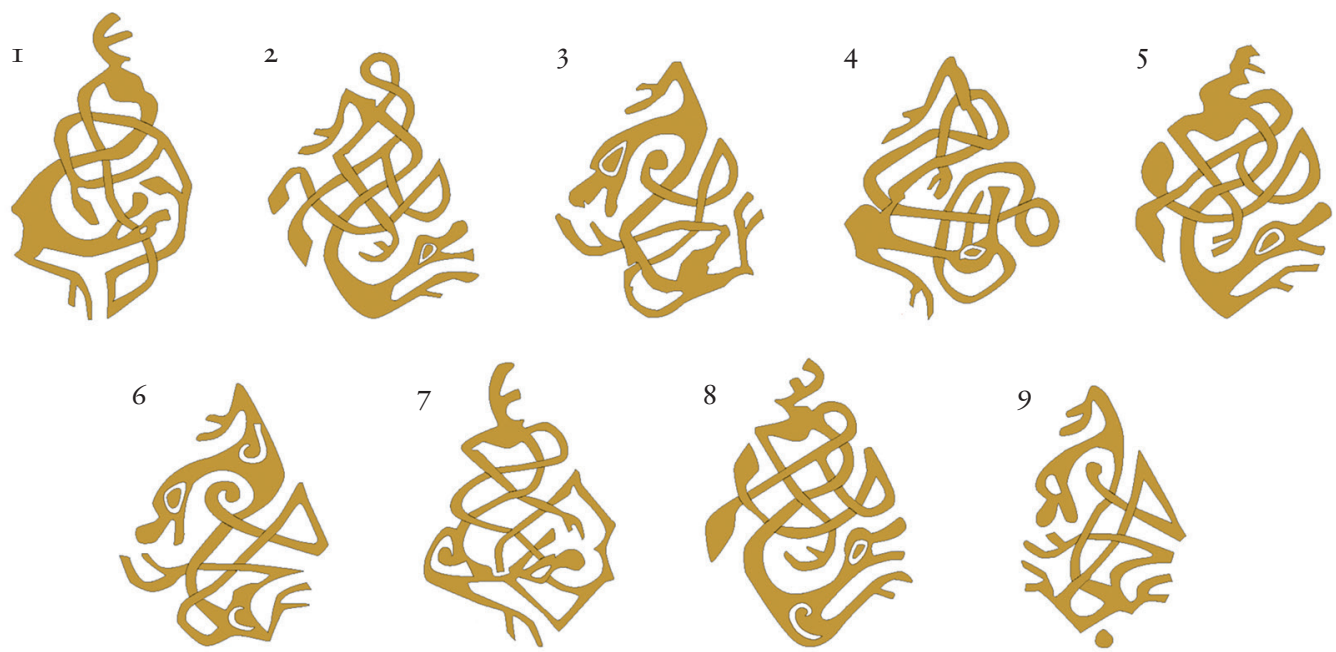

Figure 4. Tassilo-Liutpirc Chalice: the quadrupeds in row III, height: $c$. I. $8 \mathrm{~cm}$ each. Drawings: Vera Kassühlke, RGZM. After Pesch 2019:325.

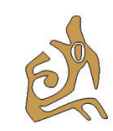

I
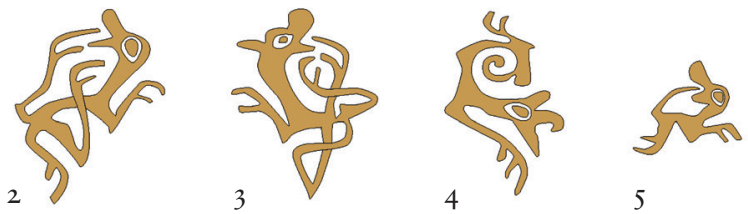

Figure 5. Tassilo-Liutpirc Chalice: the quadrupeds in row IV, height: between 0.7 and $1.2 \mathrm{~cm}$. Drawings: Vera Kassühlke, RGZM. After Pesch 20I9:325.

interlaced animals each (figure 3). While these animals basically comprise the same elements as those in row I, their body posture is different: the ribbon-body can be curved in a U-shape (II: I.5), in a loop (II: 3.4 ) or may have a straight form (II: 2). A new component is the long neck-crest, which frequently merges with either the animal's tail or tongue (exceptions: II: 3.4). Other details are hip spirals (II: 5), arched lines framing the eyes (II: 2.3.4) or different designs representing the nostrils (II: I-5), among them spirals (II: 5), which on the goblet only occur in the animals of this row. Again, the animals fill out their respective triangular fields as completely as possible. One figure in this row is unique among all the animal depictions on the goblet in that it is formed by two individual beasts within one field (II: 2). Their straight bodies cross each other and have no forelegs. Figures 3 and 4 mirror each other quite closely, as do figures I and 5 , but here only the shapes of the arched bodies correlate.

In rows III and IV, there are I 4 more animals, located around the node and in the area where the node meets the goblet's foot, respectively. The animals in row III (figure 4) occur in the rectangular or rhombic fields on 


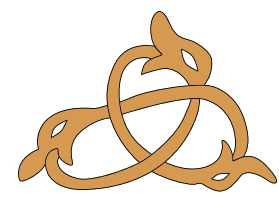

Figure 6. Tassilo-Liutpirc Chalice: one of the four triquetra symbols with animal heads in row V, height: $c$. I. $2 \mathrm{~cm}$. Drawing: Vera Kassühlke, RGZM. After Pesch 2019:325.

the node, and while resembling those of row I in appearance, they vary from them in general orientation, as the different forms of the fields necessitate a different arrangement of components and ribbon loops. It is interesting to note that there are almost exact repetitions in individual motifs with only minimal variations (III: I.7; III: 2.8; III: 3.6.9). Several of the animals have a forked tail or two tail-ribbons (III: .2.5.7.8), one - apparently for reasons of symmetry - has three hind legs (III: 9), and three bite their own tails (III: I.4.7).

Unlike those mentioned above, the fields in row IV with animal figures (figure 5) are not of equal size and shape. They represent the 'residual' spaces, which were created by the overriding architectural organization of the goblet's decoration and filled with either animal figures or symbols, such as the triquetra (see below). Only the animal's head and a foreleg are easily recognizable in all instances, while the rest of the bodies are abbreviated or designed in different ways. None of the animals matches the patterns discussed above. There are ribbons with their ends in the shape of a foot as well as animals with three legs (IV: 2.3). Three animals seem to bite into their own tail or foot (IV: 2.3.5), and in two cases ears can be seen (IV: 3.4 ). The greatest variations occur in the smallest animals (IV: I.4.5), one of which sports a neck-crest (IV: I), and another a fishtail-like coil attached to one hind leg (IV: 4).

Finally, in row V, just above the inscription circling the edge of the goblet's foot, four identical figures in the form of a triquetra are added (figure 6). They represent either one serpentine beast with three heads or three animals, each of which is biting the tail of the one in front of it. Thus, the triquetra's loops appear, as Günther Haseloff put it, 'zoomorphed' (I979:43).

The backwards-looking animals in row I (figure 2) take a crouching position, but their body posture and the forelegs pointing upwards indicate movement and create the impression that they are in the process of jumping up. In their attitude and vigour, they have a heraldic quality. In comparison, the animals in row II (figure 3) appear to float or swim, as their bodies were detached from the ground. An equally detached, but considerably less confident image is conveyed by the figures on the node in rows III and IV (figures $4 \& 5$ ): They appear to wriggle or thrash about, as if they had fallen into the water and were struggling for their lives. All of them, however, clearly demonstrate that filling the predefined spaces was the artist's primary aim. 

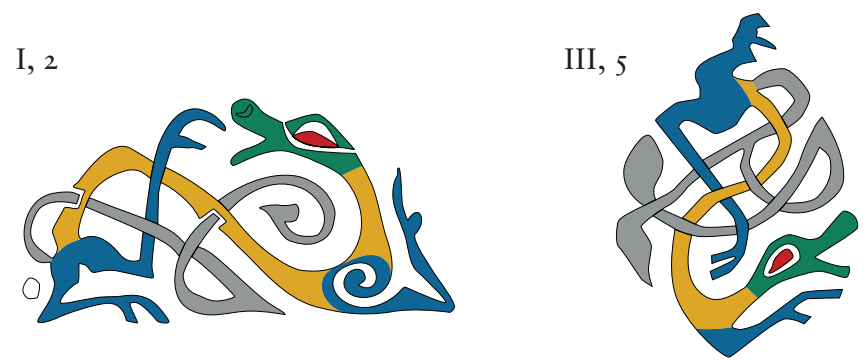

Figure 7. Tassilo-Liutpirc Chalice: two quadrupeds (row I, 2; row III, 5) with colour highlighting of their body parts: red $=$ eye, green $=$ head with mouth, orange $=$ neck and body $(\mathrm{s}$-shaped $)$, blue $=$ limbs, grey $=$ tail/ribbons. Drawing: Vera Kassühlke, RGZM. After Pesch 2019:323.

\section{Criteria of the animals' design}

It is noticeable that the animals' design is not at all naturalistic, but stylized to a high degree. All of the animals of rows I to IV are composed of the same basic elements and are quite easy to read - at least for scholars acquainted with the imagery and artistic conventions of the animal styles (figure 7). No two figures are drawn exactly alike, and the posture and orientations vary as well; a general order or direction in the positioning of the individual figures is not apparent.

The animals are quadrupeds, invariably shown in side view, and always with the same slender, long ribbon-body, which frequently is curved in an $\mathrm{s}$ - or z-shape or occasionally in a loop or u-shape. Regarding the limbs, it is common for only three legs - one foreleg and two hind legs - to be shown. In their proportions, body and limbs do not match, and often one hind leg is represented considerably longer than the other. Some of the animals display further abbreviations, especially those in the small fields of row IV (figure 5). The underlying principle in the design of the animals lies in the variation of a basic model and its components. Essentially, it is always the same animal, which is varied by the use of different orientations, body postures, the number of limbs, or additional ribbon loops. This creates the impression of variability without there actually being any real diversity in the forms and figures.

There is no naturalism in the images. Only a few of the animals on the Tassilo-Liutpirc Chalice have any characteristics that would distinguish them from the others or even make the idea of a zoological identification conceivable. Two figures in row I (figure 2, I: 4.9) feature a tail with a trilobate end, which in medieval art was often, but not exclusively, used for depictions of lions. The presence of pointed ears on the heads of two other animals in this row (figure 2, I: 7.8) might indicate lions as well (see below), 
but this interpretation is not at all convincing. Depictions of lions have a long tradition (Wamers et al. 200I), as they were an important element of the iconography of power in the Ancient Orient and in Antiquity. Often, they acted as guardians, positioned at entryways and especially in front of palaces and thrones, or flanking the image of a deity, or later of a saint; they highlighted the power of the individual by their presence. In Christianity, therefore, lions are very suitable for underscoring God's power and glory.

A striking feature is the very regular way the animals and floral elements alternate, each always (with the exception of the goblet's foot) occurring in equal numbers. 'Animal ornaments and floral ornaments [...] are standing side by side entirely as equals' (Haseloff I95 I:8). The importance of taking an overall view of these and other elements has been pointed out repeatedly, especially by Egon Wamers (e.g. 20I3:438).

It is not a surprise that animal figures occur on objects of Christian art. As all the occidental iconographies or pictorial languages are based on traditions of Antiquity, they are all characterized by a certain penchant for images of animals as 'purveyors' of messages of salvation. As far as the motifs are concerned, the animals of the Tassilo-Liutpirc Chalice may well be linked to Mediterranean parallels - this is not the case, however, regarding their style.

\section{On the animals' style}

The animal figures of the Tassilo-Liutpirc Chalice are not unique phenomena in their time horizon. There are parallels, both on sacral and profane objects, which are very similar in stylistic execution. These examples have been compiled repeatedly in the past (e.g. Haseloff 1951:I9-49; Werner I959), but the studies put their emphasis mainly on high-profile artefacts, and initially on objects - not only metalwork, but also richly illuminated manuscripts and stone sculpture - from the foothills of the Alps in southern Germany. The occurrence of stylized animal figures in old Bavaria and the workshops in Tassilo's sphere is remarkable, and scholars long since have understood this as a characteristic feature of the Salzburg region.

A few examples will illustrate this. The older Lindau book cover (Pierpont Morgan Library, New York, MS. M. I) features a variety of styles similar to the Tassilo-Liutpirc Chalice, with intertwined animals - quadrupeds and snake-like beasts - filling the fields in the spandrels of the central cross pattée in much the same way, each interwoven with their own long limbs and those of other animals. The design of the heads of the quadrupeds and their bodies with their two hind legs spread wide forms a link to the animals of the chalice. A bit more corporeal in comparison are the 
a

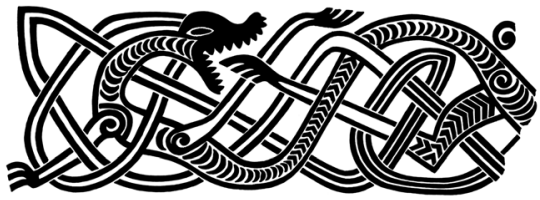

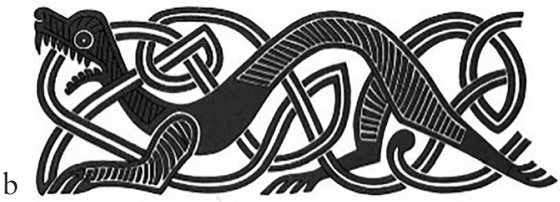

Figure 8. Two animal figures from the choir screens in St John Abbey in Müstair, Switzerland, with ribbon-bodies, entwined in interlace, looking backwards and forwards, respectively. After Haseloff I980:27, 29.

animals from the fragments of the famous choir screens of St John Abbey in Müstair, Switzerland (figure 8). In basic design, body components and ribbon loops, they resemble the animals of the Tassilo-Liutpirc Chalice (Haseloff I980; Elbern I990; Roth-Rubi 20I9), especially those of row I, in that they too are quadrupeds, either looking forwards or backwards, but with rows of pointed teeth which might characterize them as predators.

It has been surmised that the origin of animal figures and animal heads on high-level objects in the Salzburg region, and thus the home of the 'style conglomerates', was to be found in local workshops, and more specifically in the monastic and court workshops of Tassilo and Liutpirc (Wamers 20I9a). According to Katrin Roth-Rubi, these animal figures are almost a 'specific of Bavarian court art' (20I9:3 I I-I2; see also Swarzenski I9I3).

For a long time, the focus of previous studies about the animal figures has been on the definition and derivation of their style (for research history, see Prochno 2005:I66-I69; see also Žvanut 2002:274-279). Apart from 'Animal Style III' (Germ. 'Tierstil III': Bakka I983), some other names for the style have been suggested that highlight its affinity with Irish and English products, such as 'Insular style' (Haseloff I987; Werner 1959; Elbern I990; Roth, U. 2002), 'missionary style' (Bakka 1983:54), 'HibernoSaxon style' (Haseloff I95I:25; Roth, U. 2002:219), 'Anglo-Carolingian style' (Wilson I960:I6I) as well as 'Insular style of Continental persuasion' (Bierbrauer, K. 200I). Now, the simplifying term 'Tassilo Chalice style' is widely used by scholars (Wamers I99I:I24-I26, I993, I999:205-207, 2005:294, 2008:37-39, 2013:428), originally introduced by Frauke Stein (1967:46). All these terms, however, refer to the animal figures without taking the complete style conglomerate of the chalice, and of the other objects, into account. At the same time, justified doubts have been cast concerning whether all the different elements can be defined as one coherent style in the first place (Capelle 1998:368-369; Ament \& Wilson 2005:594-595).

How did the animals enter the pictorial programme of the chalice, and what social or religious backgrounds and communication systems can be deduced? 


\section{Ancestry of the chalice's creatures}

It is widely considered beyond dispute that the animals of the TassiloLiutpirc Chalice and related objects are closely linked to animal figures in England and Ireland, that is, from Insular Britain (e.g. Haseloff I95I:I3, 2I-33; Bakka I983; Bierbrauer, K. 200I). In particular, illuminations in manuscripts produced in this area offer a wealth of parallels, including, for example, similar stylization of the figures, their body postures and criteria for all details of the design. Among them are magnificent pieces of art of the seventh and eighth centuries, such as the Book of Durrow (figure I4; Dublin, Trinity College, TCD MS 57) and the Lindisfarne Gospels (London, British Library, Cotton MS Nero D. IV) (Holländer I98г:23, 29; Henderson 1987; Brown 2003a, 2003b, 2007; Webster 20I2:75-88; see also Roth, U. 1987, 2002). Their carpet pages, initials or other illuminations are alive with a very similar fauna of quadrupeds (as well as birds, which are completely absent on the Tassilo-Liutpirc Chalice), which are equally characterized by the interweaving of their own slender limbs and long ribbons or by other details such as small heads with almond-shaped eyes and plump upper jaws ('duck's heads': Haseloff I95 I:I9). In particular, the small hip-spirals of several animals in row I of the Tassilo-Liutpirc Chalice (figure 2, I: I-6.9.IO), as well as the less common spirals of the nostrils in row II (figure 3, II: 4.5), are derived from Insular imagery, where they represent typical stylistic elements in manuscripts or stone sculpture, such as high crosses (Haseloff I95 I:33; Bierbrauer, K. 200I:I I6-I I 7). It has not yet been possible to determine the connections between Insular art of the seventh to ninth centuries and similar phenomena of the late Merovingian and early Carolingian periods on the Continent with precision due to stylistic and chronological problems (Wamers 20I3:440). However, there is hardly any dispute among scholars about the role the Insular mission played as a motor and mediator for the style's distribution on the Continent. Another argument in favour of this notion is the chalice's interlace ornament with its close parallels to Insular art.

These parallels can be explained with reference to the work of the monks associated with Virgil, Tassilo's court scholar. In 745/46, the Irish monk Virgil came to Salzburg, became abbot of the monastery of St Peter, and was made bishop in 749. As spiritus rector, he exercised considerable influence on Tassilo until his death in 784 (Wamers 20I3:442, 20I9a:386-387). He was, of course, not by himself, but several other monks and clerics had come with him, a veritable retinue of scholars and artists, who cultivated the knowledge and skills they had brought with them into old Bavaria, and eventually passed it along. Accordingly, the Salzburg area was called an 'Insular art province' by Günther Haseloff, coining a term that later was fre- 
quently adopted (Haseloff I951:67, I987; Elbern I990; Wamers 2019a:388; cf Žvanut 2002). Nevertheless, the imagery of the region retained its own character, and it is interesting to note that the Insular curvilinear art or 'circle ornamentation' (deriving from Celtic art) is virtually unknown here.

A special case, different from all other animal figures, is seen in the trefoil-loops with heads in the chalice's row V (figure 6). These are based on a symbol, the trefoil-knot or triquetra (see Trætteberg et al. 1982). Formally, the design is created by the intersection of three circle arcs. The term comes from the Latin adjective triquetrus, 'three-cornered', and the symbol is not to be confused with the triskelion (which has three bent arms/feet emerging from a common centre). The design derived from interlace ornamentation. Triquetras have a clear connection to early medieval sacral art, and are considered Christian symbols that reference the Holy Trinity. The symbol began to occur in its perfected form during the second half of the seventh century, and is found, for example, on famous objects like the armrests of the friths stool in Hexham Abbey, England; a bishop's chair supposedly from the late seventh century; and, on the front of Franks Casket, in a scene depicting the Three Magi. It is uncertain whether simple trefoil-loops (occurring in the early seventh century, for example on the great purse mount found in the 'princely burial' in Beckum, Germany, along with Solomon's knots) - might be identified as precursors of the triquetra, as they do not yet achieve the well-balanced clarity of the true triquetra. Triquetras are frequently components of the decoration of illuminations in Psalters, Evangeliaries and other manuscripts, particularly in England and Ireland, but are equally common in Continental reliquaries (e.g. Quast 20I2:pl. 4, I2, I8, 2I) and eighth-century chalices (e.g. the 'Cundpald chalice' or the 'Grimfredus chalice': see Elbern 1963; Werner 1966; Bierbrauer, V. I988; Ryan 2019; Wamers 2019a:393-396). They also occur in architecture (albeit only rarely at first), for example in Müstair (see Roth-Rubi 20I1:75, figure I2). In Langobardic Italy, with its sophisticated culture of interlace-ornamented stone sculpture, they reached their heyday, especially during the tenth century. In this period, they also find wider distribution in Nordic coinages in England and south Scandinavia, on jewellery in Viking contexts, such as three-lobed brooches or filigree Pressblech pendants or on stone sculpture, for example the great Jelling stone in Denmark and Insular high crosses (such as the cross in Gosforth, Cumbria, England). Gotlandic picture stones also display them, but here the symbols were often modified and developed into the so-called valknut, which appears either as an angular variant of the triquetra or, in an extended form, as Borromean rings, a symbol made up of three separate triangles interlaced with each other.

Thirteen triquetras are found on the Tassilo-Liutpirc Chalice (Wamers [ed.] 20I9: folding plate 2). Of these, five are located on the bottom of the 


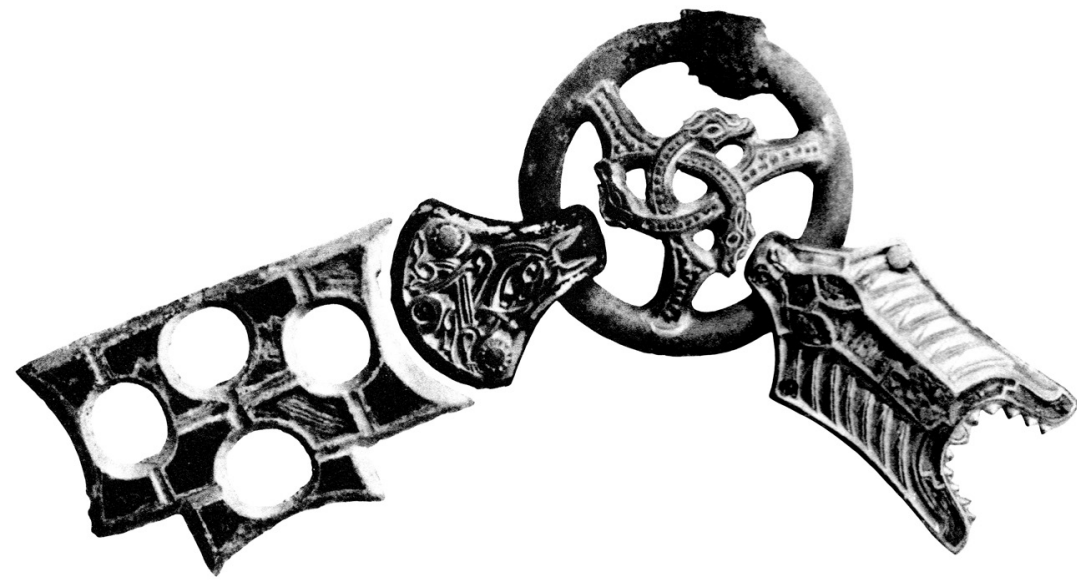

Figure 9. Vendel, Uppland, Sweden, grave 3: centre ring of a belt distributor of a bridle, featuring a triquetra with animal heads. After Arwidsson 1942:Abb. 53.

cuppa, in the spandrels under the medallions, and four more on the lower part of the node, where they alternate with the animal figures of row IV. Special prominence was afforded to the four triquetras of row $\mathrm{V}$, in the lower spandrels between the medallions on the goblet's foot, which were modified by the addition of animal heads (figure 6). Such a detail once again refers to the Insular area. In the manuscripts, ribbons, knots and interlace patterns are common, and are 'zoomorphed' in a similar manner, for instance in the 'Petersburg Evangeliary' (England, second half of the eighth century; see Stiegemann et al. 20I3:238). A striking parallel to these symbols, however, is found on an eighth-century bridle mount from the Swedish grave-field of Vendel, grave III: on it, an almost identical figure can be seen that is different only by the elongated points of the symbol's three corners (figure 9; see also Stolpe \& Arne I9I 2:pl. I3). There are several more triquetras in the graves at Vendel, for instance on the knob on the apex of a shield boss in grave I. Another very good parallel, however, is a figure on a pommel from the famous Staffordshire hoard from England (figure Iо; see Fern et al. 2019:39-40, 247). Little is known about the workshops producing high-quality artefacts such as these (Pesch \& Blankenfeldt 2OI2; Fern et al. 20I9:I24), but parallels between many of the objects from Vendel (and from eastern Sweden, including Gotland, in general) and those of the Insular region have been recognized for some time. The Vendel Styles, and the East Scandinavian Style III as well, are closely related to the ornamentation of contemporaneous Insular products. The rare symbol of the triquetra with animal heads binds the three regions together as parts of one iconographically connected area. 


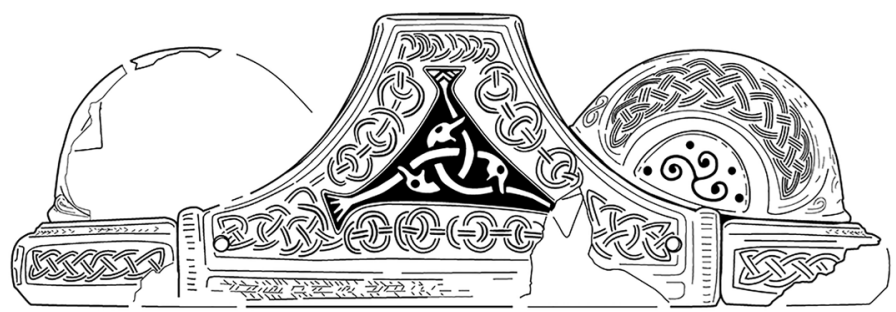

Figure Io. Sword pommel no. 76 from the Staffordshire hoard, featuring a triquetra with animal heads very similar to the one the Tassilo-Liutpirc-chalice. Data copyright $(\odot)$ Barbican Research Associates, Birmingham City Council, Trustees of the British Museum, Stokeon-Trent City Council, Birmingham Museums Trust (doi:IO.5284/IO4I576).

[NB:This work is licensed under the ADS Terms of Use and Access; see: The Staffordshire Hoard: an Anglo-Saxon Treasure: Downloads (archaeologydataservice.ac.uk) ]

\section{Parallels in the Germanic animal styles}

Figuring out something about the roots of the chalice creatures is not only intriguing in itself, but also provides hints as to the mental, cognitive and social streams behind the designs. In this case, they mirror cultural stability and integrity as well as transformation and renovation. This can be deduced by a careful re-examination of the older Germanic Animal styles and by contrasting their design principles with those of the animals on the Tassilo-Liutpirc Chalice.

A derivation of the chalice's animals from the preceding Germanic Animal Style II has been discussed many times due to some obvious similarities in the styles. A direct link, however, was ultimately rejected by most scholars (Bakka I983:19; Bierbrauer, V. 200I:I04). Even though he identified the precursors of several elements of its design in the backwards-turned figures of Animal Style II, Günther Haseloff rather believed in 'primitive' new creations in the imagery of the chalice (Haseloff I95I:I2, 20-2I). In fact, the specific expressions that characterize Style II in the South and distinguish it from its Northern European and Anglo-Saxon variants (figure I5b) render the idea of such a derivation implausible. In contrast, Katja Žvanut (2002) argued that the animal figures on the chalice and their relatives represented a continuation of Style II and should be seen as the expression of an older Germanic identity.

Since its very beginnings during the Roman Iron Age, Germanic art (Roth, H. I998; Ament \& Wilson 2005; Pesch 20I2) was inclined to stylize. Naturalism, which is characteristic for Roman imagery, is unknown to it, even though it primarily draws on these Roman roots for inspiration. During the fifth century, an image system that was like a true pictorial language took shape in the European North, and by the second half of 


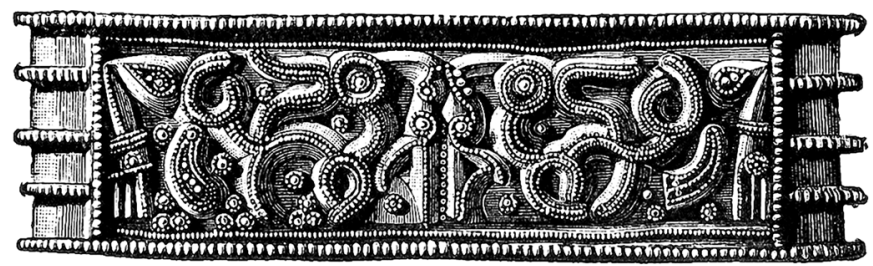

Figure I I. Two backwards-looking animals with ribbon-bodies on a golden scabbard locket from Mellby, Västergötland, Sweden. Width: $7 \mathrm{~cm}$. Fifth or sixth century. Drawing: K. Stjerna I9I2. After Pesch 20I5:239.

the sixth century, its original and lively ciphers had achieved a wide distribution on objects of all sorts, throughout all of Northern Europe and the Germanic-speaking regions. Other image systems or art styles did not play any role in these areas. As a consequence, the Animal Style I is now considered to have been a medium of communication between the Germanic elites, as well as an expression of their common identity (Høilund Nielsen I998; Pesch 2007:38I-384). While it may appear fanciful, it was still characterized by strict design guidelines and possessed only a limited range of motifs and forms. These guidelines, which govern all Animal Style I images, are of some interest with regard to those of the animal figures of the Tassilo-Liutpirc Chalice. As mentioned above, the goblet's animals essentially are variations of one basic figure, only distinguished from it and each other by individual stylization, abbreviation and/or the addition of details or components, or by the repetition and sequencing of animals. All of these characteristics were already of greatest importance in Animal Style I (Pesch 2015:509), and other central features, such as the narrow ribbon-body of the goblet's animals, are very common here, too. These similarities can be illustrated with just a few examples.

Figures resembling those of row I of the Tassilo-Liutpirc Chalice, as far as their basic design regarding presentation and body posture is concerned, can be found on a Swedish scabbard locket mount from Mellby, Västergötland (figure II), for example, or on fifth- and sixth-century gold bracteates (small pendants serving as amulets), which in their figural images display many variants of animal figures in Animal Style I (figure I2; see IK; Pesch 2007; Hauck 20II). The range of motifs of the latter group is rather limited: D-bracteates of the first half of the sixth century use animals - predominantly variants of the quadruped with ribbon-body and bird's beak ('griffin') - as their main motif to completely fill the available image area. Accordingly, it is not correct to assume that ribbons and ribbon-bodies first appear with Style II, as Haseloff stated (I95I:20). The s-shaped curve of the ribbon-body on the bracteate IK 468 from Nebenstedt, Germany (fig- 

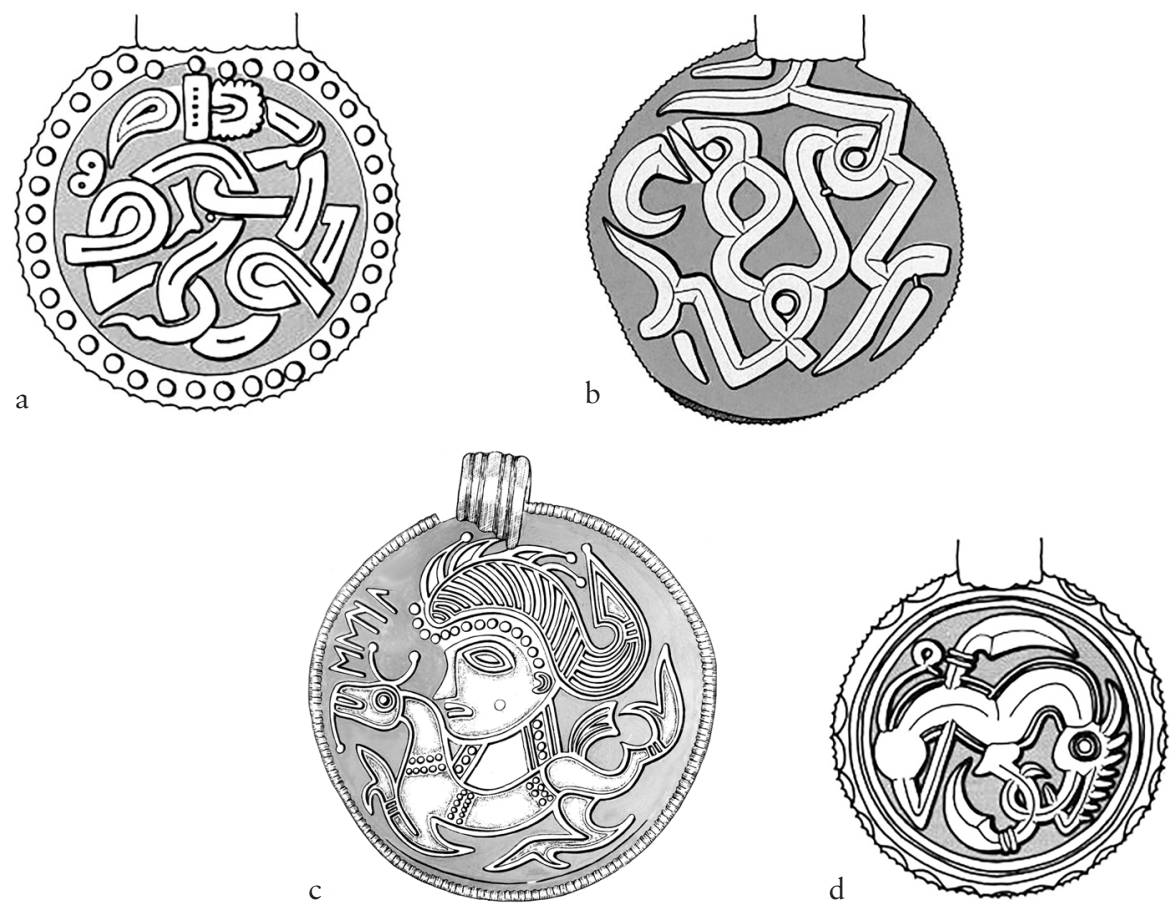

Figure I2. Gold bracteates of the fifth- and sixth centuries, with comparisons to the quadrupeds on the Tassilo-Liutpirc Chalice: a. D-bracteate IK 468 Nebenstedt, Lower Saxony, Germany, diameter: $2.6 \mathrm{~cm}$; b. D-bracteate IK 5 I6 Skovsborg, Denmark, diameter: $2.5 \mathrm{~cm}$; c. C-bracteate IK 233 from Djupbrunns, Gotland, Sweden, diameter $2.75 \mathrm{~cm}$; d. image field of the D-bracteate IK 563 from Voll, Rogaland, Norway, diameter: $2.3 \mathrm{~cm}$. After IK.

ure I2a), is a characteristic trait of this kind of animal figure, which is also apparent on the chalice. The two legs emerge from hip loops and are coiled around the animal's body. Other common features on the D-bracteates are the neck-crest, the quadruped's angled feet, occasionally with only two toes, turned back against the legs, which in turn are often raised up and held over the animal's body (figure I 2 b). This ensemble of elements anticipates, as it were, many characteristics of the animals of the Tassilo-Liutpirc Chalice. The only element missing on it - though very common in Insular and Carolingian art - are the ribbons that grow out of tails, tongues or neck-crests and form knots and loops around the animals' bodies. On the bracteates of Type C, which were produced after the middle of the fifth century, it is easier to read the animals. They feature a large anthropomorphic head above a stylized quadruped (horse), which occasionally is depicted with only three legs and with the hind legs shown spread out in opposite directions, as seen on IK 233 from Djupbrunns, Gotland (figure I2c), for example. This peculiar body posture must have a special significance, as it 


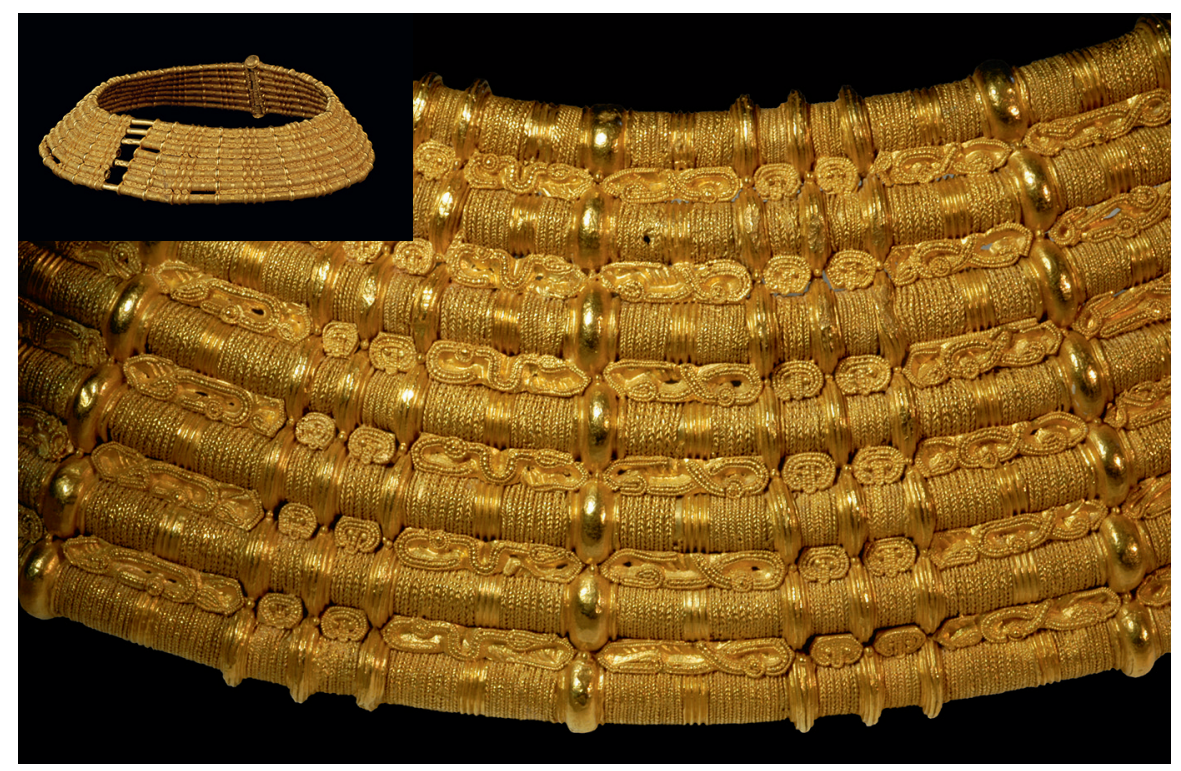

Figure Iza. From the highest strata of society: gold collar from Möne, Västergötland, Sweden, sixth century. There are 398 tiny animals and human faces in six rows between the collar's seven concentric rings, predominantly variations of a basic form of a quadruped with ribbon-body. Essentially, they always display the same body posture, but frequently are abbreviated in the upper area. Photographs: Barbara Armbruster.

is not merely the result of the round shape of the image area; other bracteates feature entirely different positions of the legs.

Repetitions and sequences of animals - that is, stringing together identical or slightly varied figures in rows - are popular style criteria in animal ornament. Masterpieces of this device are the three Swedish gold collars (Holmqvist I980; Lamm 199I; Pesch 2015). The largest example, the collar from Möne (figure I3a), was made during the late phase of Animal Style I and is particularly suitable for a comparison. This extraordinary piece of jewellery, surely fabricated for a supreme leader of society, is made completely out of gold. It features 384 animal figures arranged in six rows of concentric rings. Their bodies were cast in half relief on tiny gold tablets and then traced with filigree and granulation. In most cases, they are highly stylized ribbon-bodied quadrupeds, shown in side view. The animals have been grouped into five variations (Pesch 2015:237-240) according to the shape of the bodies - in u-shape, coiled, folded back, looped or being intersected by the animal's mouth (figure I3b: 5). With the exception of the last, all of these variations are represented in the animals of the Tassilo-Liutpirc Chalice.

Usually, the surfaces of objects decorated in the Animal styles are filled in completely with one or several animals and other ornaments, often with 

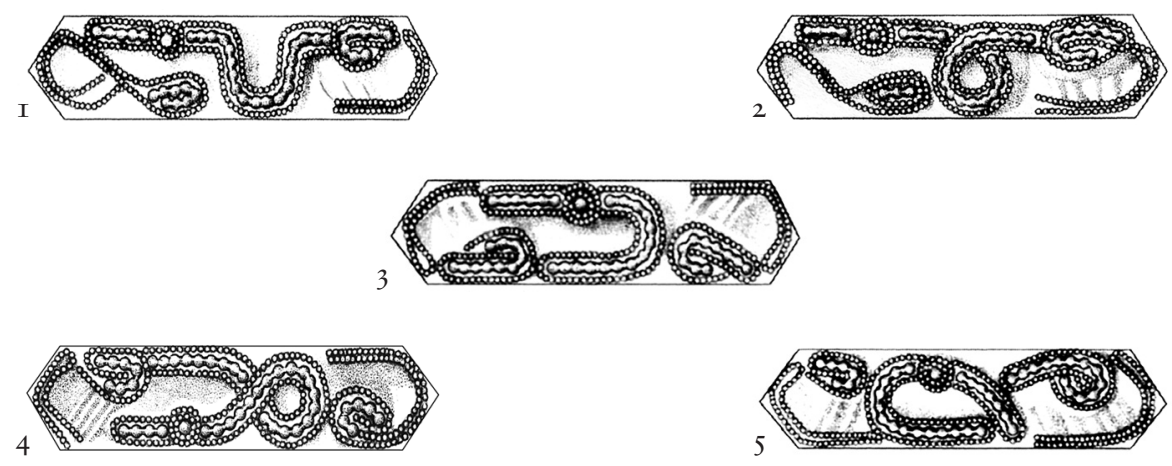

Figure I3b. Forwards- and backwards-looking animals with ribbon-like bodies on the gold collar from Möne, Sweden. Variation such as this is characteristic for Animal Style I. Length: $c$. I. $4 \mathrm{~cm}$. After Pesch 2015:2452-50.

chip carving, leaving no empty spaces at all. Günther Haseloff referred to this phenomenon as horror vacui, and it is also one of the basic determinants of animal style art (Haseloff I98I:I I3-I I 4). The effect is achieved by the animals' limbs being positioned in unusual angles or by drawing them as displaced, twisted, elongated, enlarged or shortened. This also is represented in the animals of the Tassilo-Liutpirc Chalice.

Thus, it must be noted that almost all elements of stylization seen in the animals of the later Salzburg art are already present in Style I produced between the middle of the fifth and the middle of the sixth centuries, such as the components of the animals' shape, the arched, ribbon-like bodies, their postures and even the design of individual details.

Animal Style II (after Salin 1904), which emerged in the late sixth century and remained in use until the final third of the seventh century, formed a new phase of animal ornamentation, and while replacing Style I, it adopted and continued many of its principles and criteria. The Style I pattern of the animal figure with its head turned backwards and either intersecting or biting its own body, was modified by Style II in many ways (figure I5). The two animals on the mount from Mellby (figure II) are an example of this pattern, and along with the s-shape of their bodies and the raised foreleg, they represent a good parallel to the figures on the chalice (see row III; figure $4: 3.6 .9)$. A main characteristic of Style II is that the general order of the animals is even more ornamental. Now, the animals usually appear in groups, intertwined with each other, often in a symmetrical design, and either form regular rhythmic interlace patterns or at least are drawn based on such patterns (Haseloff I979a:42-5I; Roth, H. I986:I39; Ament \& Wilson 2005:593). With this 'interlace basis', an element was integrated that had been developed in the imageries of Mediterranean Antiquity. Accordingly, scholars assumed that Animal Style II was invented in the cultural 
'contact zone' of southern Germany and northern Italy (Haseloff I974). Equally possible, however, is the transmission of these elements via the Insular style, which had adopted interlace ornamentation at an early stage, and developed it to perfection. But, as was stated, it might be 'wrong to look for a single point of genesis' (Fern et al. 20I9:2II) in the first place.

\section{Workshops and societies}

How can the connections be explained between design elements in the old Germanic animal style and the animals of the Salzburg school? What social and cultural ideas lay behind the incorporation of animal figures within an entirely new context, and where might the link be found? The key may lie in the study of the workshops.

Outstanding pieces of art such as the gold collars demonstrate the existence of highest quality workmanship in the fifth and sixth centuries. Workshops produced many different objects from precious metal, such as brooches, bracteates, helmets, swords, and fittings for clothes, belts or horse harnesses, in each case designed with the same overall corporate style criteria and shapes. But even before that, not later than the third century, there are indications of similar facilities processing precious metals. Archaeologically, however, there are very few traces, such as waste metal from casting, of the locations. Therefore, we can only speculate about the sizes and numbers of these workshops as well as about the training, the social status or the number of people working in them (Pesch \& Blankenfeld 2OI2). Highly qualified workshops for precious metals may have belonged to rulers and kings, who would have been their patrons and who were able to finance and protect them (Hardt 2004, 20I2). But even when these rulers were replaced, the same workshops apparently continued to function, as the same types of objects remain in production for long periods of time and encompassing a wide spatial distribution. That means that at least some workshops must have been able to remain active for centuries, steadily contributing to the cultivation and advancement of the common visual art. The network of workshops was closely linked to the higher strata of society, but at the same time it was somehow independent from personal taste and habits, and thus independent from individual rulers. This autonomous character seems to have been a constant feature of the workshops. Regular and long-distance communication between the workshops, for instance by systematic exchange of craftspeople, enabled common developments that quickly acquired supra-regional value.

Germanic image composition has always been synthetic and integrative (Pesch 20I2:687). This visual art was never static. Since its beginnings, it 
adopted other traditions, predominantly Roman examples as models for its own imagery and semantics of images. Celtic and Gothic elements were integrated as well as those of nomadic steppe cultures. This always resulted in very idiosyncratic, characteristic and frequently clearly defined images or products that nonetheless were virtually identical even over long distances.

In the seventh century, Christianity began to be practised across large parts of England (Scull 20I5). Evidence of this transition from the preChristian to Christian era has been found for example in the recent excavations from Rendlesham in Suffolk, a central place or royal settlement of particular importance (Scull et al. 2016). During the same period on the Continent, Franks and other Germanic peoples also accepted the new faith. Yet, the recently converted rulers maintained their close connections with their respective workshops. Their ties to Christianity resulted in new forms of visual art, as - in time-honoured fashion - Mediterranean traditions and influences were adopted (Wamers 2008a). The workshops, however, also continued many of their old traditions as well (see also Herman 20I7). Animal Style I, which until that point was employed in all Germanic workshops with only minor regional differences, was not entirely abandoned by the artisans. Instead, they modified its sophisticated language of images by introducing new details and new organizational criteria, and in doing so, they created Animal Style II. Thus, throughout the ages the common approach and constant communication within the network of workshops ensured the wide distribution of the uniform styles in the Germanicspeaking regions, from the pagan to Christian periods. Compared to the time of Style I, however, there was now an increase in localized characteristics. One early epicentre of the new style appears to have been England, as attested to by high-quality products such as the material in the grave at Sutton Hoo (after 625), the Staffordshire hoard (late seventh-century), and many other artefacts.

Even before these developments, craftspeople in England and Ireland had picked up styles and motifs from older traditions: in their work, highly complex Celtic curvilinear art (Guichard 20I 2; Webster 20I 2:99-I II) met Romano-British imagery and Germanic Animal style (Zarnecki 1990), which had flourished there - especially in metallic art - since the immigration of peoples from Scandinavia and the southern coastal areas of the North sea. Being masters of syntheses such as these (Holländer I981:IOII), Christian artists also incorporated antique interlace ornaments, as well as late-antique Salvation imagery with its 'tree of life' symbolism, motifs of inhabited vine scrolls, leaf tendrils of paradise and Mediterranean formats of figural representations (see Bauerreiß I938; Buchheit I990; Wamers 20I3:430-432). Thus, many different image systems and pictorial languages came together in skilled Insular artwork (Werner I959:I9I-I92; Haseloff 
I979b:225-227; Bierbrauer, V. 200I:I 20), the workshops merging them all into a new Christian iconography.

In this manner, animals made their way into books (Zarnecki I990:I92194). For example, animal figures shown in rows and/or interlaced with each other feature in the Book of Durrow (Wilson I986). This manuscript was probably made in the second half of the seventh century. Here, in a famous carpet page, stylized animal figures, combined with curvilinear ornamentation, surround a Byzantine cross (figure I4). Motifs such as these animals are frequently termed as 'Style II on parchment' by scholars. A comparison with a sword hilt fitting from the Staffordshire hoard, as one of several examples in metalwork, reveals astonishing similarities in terms of design (see Fern et al. 20I9:2 IO). The adoption of animals into the visual art of the seventh and eighth centuries was probably carried out primarily in monastic and royal workshops in England, where, as mentioned above, animal style traditions of the highest quality were still alive.

Particularly in Northumbria, the new, synthetic visual art was brought to perfection (Hawkes \& Mills I999). At first, curvilinear ornamentation, Mediterranean models and animal style would occur only on separate pages of the same manuscript, but they soon began to merge into each other. That way, during the seventh century, the new Insular imagery emerged (Haseloff I95 I:23; Paulsen I952/53; McDermott I955; Bakka I983:23; Brown 2007:8II; Webster 20I2:99-I I5; Wamers 20I9a:387; for early Anglo-Saxon art see Baldwin-Brown I915; Brøndsted I924; Kendrick 1934, I938). This polystylistic form of art, which was bursting with colour, rhythm and vigour, was used in illuminated manuscripts as well as in metal objects for the liturgy or other clerical purposes or in stone sculpture. A prime example is the Book of Kells (Dublin, Trinity College, MS. A.I.6) from the end of the eighth or the beginning of the ninth century, which as a late example represents an entire artistic school (Dodwell 1993:90). It is characterized by its full-page illuminations (e.g. fol. 34) with alternating figural and non-figural ornaments, which, in a similar way, are found in the Tassilo-Liutpirc Chalice too.

Many first-rate workshops were located at the royal courts and created various products for them, including components of clothing or weapons (Webster 20I2:II7, I25-I32). Predominantly, however, they belonged to the great monasteries. Much is known about the organizational structure of the monastic workshops, which were often royal foundations and royal protectorates. Various different craftspeople and specialists, such as goldsmiths, scribes and illuminators, worked in close collaboration (Werner I966:268; Elbern 1964). Within their community as well as in cooperation with other monastic workshops, they developed the principles of their visual art, creating art schools, and applied their motifs and their styles to different media and products. Frequently they were presided over by the ab- 


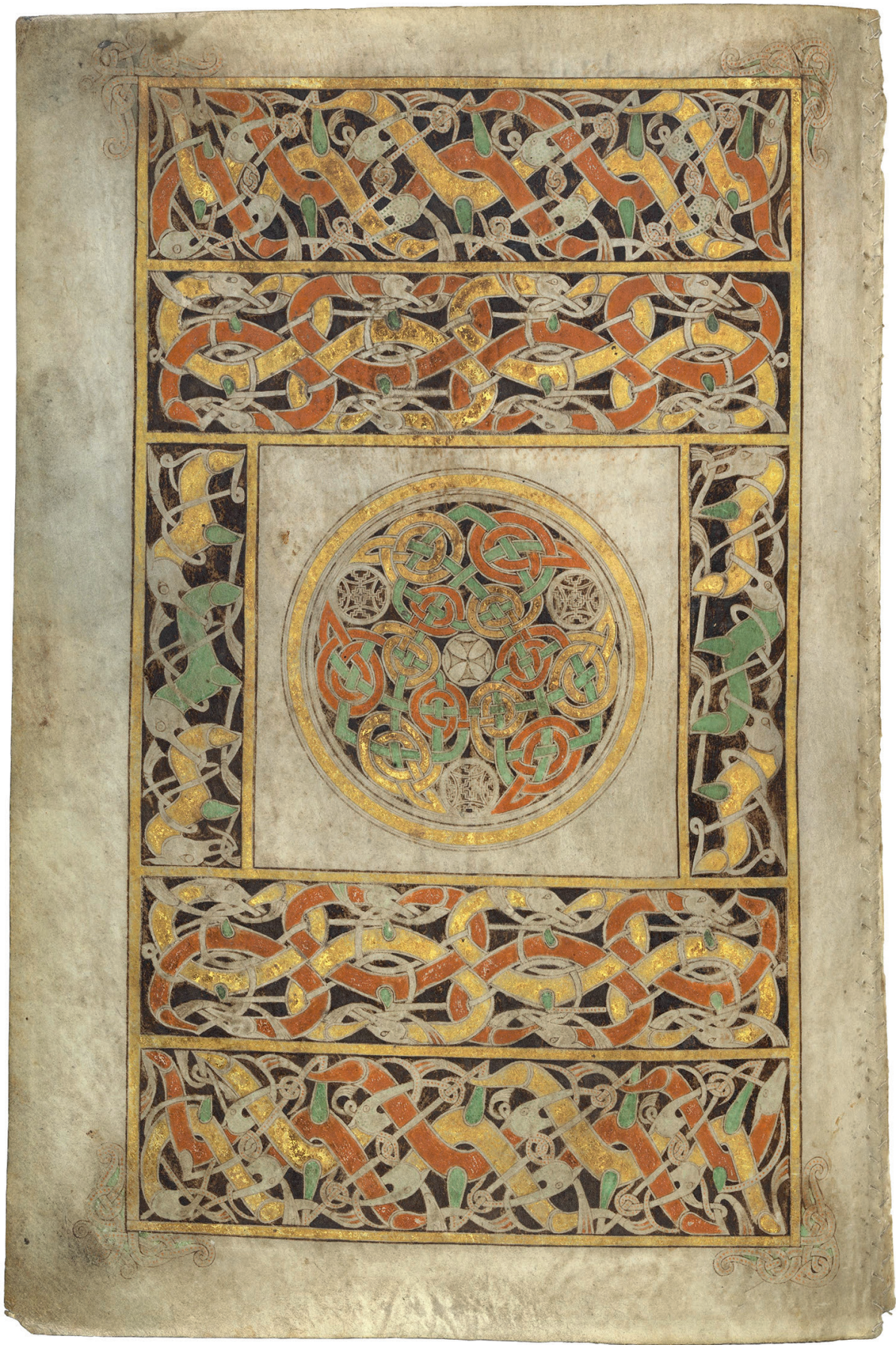

Figure I4. Carpet page of the Book of Durrow (Trinity College, Dublin, TCD MS 57, fol. I92V.), second half of the seventh century. Public domain. 
bots, who were members of the elites, and some of whom were goldsmiths themselves (Vierck 1974; Elbern 1992; Hardt 20I2; see also Capelle I982, 20I2; Carnap-Bornheim 200I). These workshops certainly produced objects for sacral purposes, such as chalices, books, crucifixes and other liturgical equipment (Elbern I963:15, 83-84), but also high-grade objects for secular uses, such as books for the members of noble families, top-class jewellery and even weapons.

There is no doubt that the workshops of Tassilo's court, especially those at the monasteries, were strongly influenced by craft traditions from the Insular region. In the late eighth century, workshops of the Salzburg area adopted several imageries and pictorial systems and merged them into a particular style of their own (Elbern 1990; Wamers 2019a; Zarnecki 1990:192). In this process, Insular and Italic/Langobardic influences played a major role as well as the further development of older traditions of Germanic Animal styles.

The monastic workshops' appeal was considerable, and on the continent secular workshops were eager to embrace their motifs and details (Werner I959:I 87-I 88; Žvanut 2002). First and foremost, during the later eighthand ninth centuries, this meant the adoption of animal images. The new imagery, which had been developed in the sphere of Tassilo's court and soon was cultivated by other important workshops, had begun to establish itself outside of sacral contexts. New finds, notably artefacts discovered by metaldetectorists over the past decades, have considerably increased the amount of reference material from profane sites. Very often, those are objects made of gilded copper-alloy. On the Continent in particular, animal figures either closely resembling those of the Tassilo-Liutpirc Chalice or their abbreviated forms, were widespread on mounts and fittings of weapons, belts or riding equipment as well as on women's jewellery (Werner 1959). Objects such as these were primarily found on the eastern side of the Rhine and northwards, up to the Elbe, thus in the formerly Germanic territories that had become part of the Carolingian Empire (Wamers 2005:294; see the maps in Bakka I983:9; Werner 1959:190; Wamers 2008b, 45, 20I3:44I). Researchers explained the popularity of the animal figures in particular by the fact that in these areas images of animals had already been so popular in Animal Style II (Werner 1959:I9I-I92). Another suggestion was the idea that these animals were the expression of opposition against the Frankish Empire, by representing symbols of a traditional, distinctly Germanic identity (Žvanut 2002:28-29). This hypothesis, however, ignores the 'detour' the animal imagery took via Insular Christian art, including the changes in contextual meaning that went along with it (Zarnecki I990; Wamers 20I3:442).

After Tassilo's fall, his workshops certainly were not destroyed without exception, but rather - whether in part or all of them - integrated into the workshops of Charlemagne's court and of those monasteries he supported. 


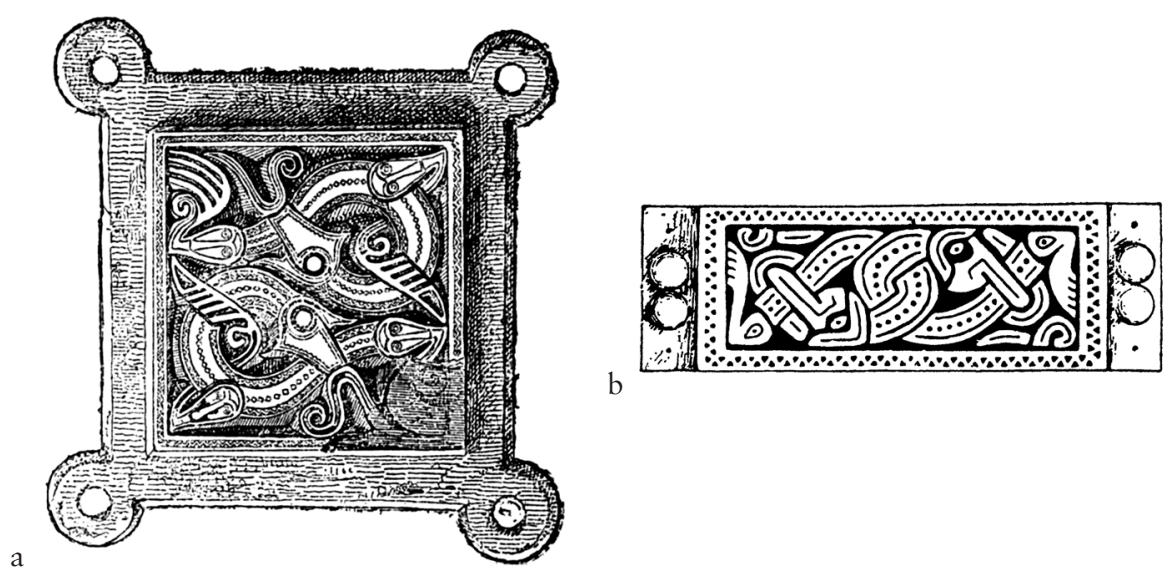

Figure I5. Belt fittings decorated in Animal Style II, sixth/seventh centuries. a. Unknown provenience in Denmark, after Salin 1904:248; b. Marzaglia, Province of Modena, Italy, after Paulsen 1967:78.

This ensured the survival of many of the style elements developed in the Salzburg school. The fact that Charlemagne maintained a strong promotion of the visual arts enabled its distribution throughout the entire Carolingian Empire (Brown 2007:I I-I2). The so-called Carolingian Style, by its very inconsistency and variability, demonstrates the continuity of the various traditions merged within it (Mütherich \& Gaerde 1976:I0; see also Mütherich 1999; Pächt 1989), also continuing old Germanic patterns of design and methods of production. Even in high medieval Romanesque art, animal figures not only played a major role in the iconography, but they still show some of the old features of the Germanic Animal styles.

\section{Significance and conclusion}

What exactly is the meaning of the various animal figures of the objects mentioned? Actually, in most instances any attempt to identify the animals' zoological species must fail due to their high degree of stylization. It seems that determination of species was not intended in the first place. Thus, an interpretation cannot be gained with the usual animal symbolism based on biology. Instead, the ciphers may refer to the anticipated effectiveness of animal pictures per se, bringing luck, strength, health or victory, representing the presence and power of divine beings, and perhaps uniting the positive effects of different kinds of animals (Pesch 2015:529-533). However, many animal figures shaped in different ways on one object gives the impression of plenty and variety. That concerns the Chalice's creatures as well as ani- 
mals on the older Germanic objects, as on the gold collar from Möne. Apparently, meaning is conveyed by the animals as a group, as a whole.

There is a high level of stylization and range of variation on the Tassilo Liudpirc Chalice, especially regarding the forms of plants and trees, which in rows I and II alternate with the animal figures. Both elements support the same message. In fact, it is reasonable to interpret the animals as part of the fauna of the Christian paradise, and like the stylized floral elements depicting vines and fruit trees, they belong to the enticing conception of a blessed world hereafter (Haseloff I95 I:49-55; Arrhenius 1986; Wamers 2005:294, 2008b:37-38, 2019b:454-456). These creatures may symbolically represent all animals of creation or even, together with the vine leaves and scrolls, for God's creation (Wamers I99I). As a whole, they support the goblet's Christian message of salvation.

Even if we do not know much about beliefs during the fifth to seventh centuries in northern Europe, their pagan background is generally regarded as factual. However, already in this state, the contexts of images lie in the religious and ideological ideas. Both Animal Style I and II carry and support messages of overall importance, and the figures are understood as symbols of protection, fortune and defence against evils. The fact that they are seen in such a positive light makes them comparable to the animals of the Tassilo Chalice and their message of salvation. To conclude, the depiction of supporting animals truly is a long-lasting feature. While societies, politics and identities constantly developed further in persistent mutual exchange, there was also an undercurrent in the form of animal figures that transcended the boundaries of epochs and religions, and which proved to be extremely resilient to many other influences.

\section{References}

Ament, H. \& Wilson, D. 2005. Tierornamentik, germanische. Reallexikon der Germanischen Altertumskunde. Vol. 30 pp. 586-605.

Arrhenius, B. 1986. Einige christliche Paraphrasen aus dem 6. Jahrhundert. In: Roth, H. (ed.). Zum Problem der Deutung frühmittelalterlicher Bildinhalte. Akten des I. Internationalen Kolloquiums in Marburg a. d. Lahn, pp. I29-I52. Sigmaringen: Thorbecke.

Arwidsson, G. 1942. Vendelstile, Email und Glas im 7.-8. Jahrhundert. Valsgärdestudien I. Uppsala/Stockholm: Almqvist \& Wiksell.

Bakka, E. I983. Westeuropäische und nordische Tierornamentik des achten Jahrhunderts in überregionalem Stil III. Studien zur Sachsenforschung. Vol. 4 pp. I-56.

Baldwin-Brown, G. 1915. The Arts in Early England. Vol. 3-4: Saxon Art and Industry in the Pagan Period. London: John Murrary.

Bauerreiß, R. I932. Der Tassilokelch von Kremsmünster und seine Inschriften. Studien und Mitteilungen zur Geschichte des Benediktinerordens und seiner Zweige. Vol. 50 pp. 408-4I5. 
Bauerreiß, R. 1938. Arbor vitae. Der 'Lebensbaum' und seine Verwendung in Liturgie, Kunst und Brauchtum des Abendlandes. Abhandlungen der Bayerischen Benediktinerakademie 3. München: Neuer Filser-Verlag.

Becher, M. 20I9. Der Sturz Tassilos III. von Baiern: Ein Vierteljahrhundert Forschungsgeschichte. In: Wamers, E. (ed.), Der Tassilo-Liutpirc-Kelch aus dem Stift Kremsmünster: Geschichte - Archäologie Kunst. Schriften des Archäologischen Museums Frankfurt 32, pp. I3 I-I 44. Regensburg: Schnell \& Steiner.

Bierbrauer, K. 200I. Insulares in der kontinentalen Buchmalerei des 8. Jahrhunderts. In: Müller-Wille, M. \& Larsson, L.O. (eds), Tiere-Menschen-Götter: Wikingerzeitliche Kunststile und ibre neuzeitliche Rezeption, pp. 63-87. Göttingen: Vandenhoeck \& Ruprecht.

Bierbrauer, V. 1988. Liturgische Gerätschaften aus Baiern und seinen Nachbarregionen in Spätantike und frühem Mittelalter. In: Dannheimer, H. (ed.), Die Bajuwaren: Von Severin bis Tassilo 488-788. Gemeinsame Landesausstellung des Freistaates Bayern und des Landes Salzburg, Rosenheim/Bayern, Mattsee/Salzburg, I9. Mai bis 6. November I988, pp. 328-34I. München: Ueberreuter Verlag.

Bierbrauer, V. 200I. Kontinentaler und insularer Tierstil im Kunsthandwerk des 8. Jahrhunderts. In: Müller-Wille, M. \& Larsson, L.O. (eds), Tiere - Menschen - Götter: Wikingerzeitliche Kunststile und ibre neuzeitliche Rezeption, pp. 89-130. Göttingen: Vandenhoeck \& Ruprecht.

Brøndsted, J. 1924. Early English Ornament: The Sources, Development and Relation to Foreign Styles of Pre-Norman Ornamental Art in England. Copenhagen: Levin \& Munksgaard.

Brown, M.P. 2003a. The Lindisfarne Gospels: Society, Spirituality and the Scribe. London/Luzern/Toronto: British Library, Faksimile Verlag \& Toronto University Press.

Brown, M.P. 2003 b. Painted Labyrinth: The World of the Lindisfarne Gospels. London: British Library.

Brown, M.P. 2007. Manuscripts from the Anglo-Saxon Age. London: British Library.

Buchheit, V. I990. Sehnsucht nach Frieden und Harmonie: Tierfriede in Antike und Abendland. Giessener Universitätsblätter. Vol. 23 pp. I09-І I2.

Capelle, T. 1982. Handwerker - Kunsthandwerker - Künstler? Fragen zur Begriffsbestimmung und zu Ausdrucksmitteln anhand ur- und frühgeschichtlichen Fundmaterials. Boreas. Vol. 5 pp. I64-I7I.

Capelle, T. 1998. Germanien, Germania, Germanische Altertumskunde, $\$ 40$ : Die jüngeren Kunststile. I. Reallexikon der Germanischen Altertumskunde. Vol. I I pp. 368-374.

Capelle, T. 20I 2. An Insight into the Goldsmith's Workshop. In: Pesch, A. \& Blankenfeldt, R. (eds), Goldsmith Mysteries: Archaeological, Pictorial and Documentary Evidence from the First Millennium AD in orthern Europe. Papers presented at a workshop organized by the Centre for Baltic and Scandinavian Archaeology (ZBSA), Schleswig, April 2oth and 2Ith, 20I I. Schriften des Archäologischen Landesmuseums, Ergänzungsreihe Band 8, pp. 17-27. Neumünster: Wachholtz.

Carnap-Bornheim, C.v. 200I. The Social Position of the Germanic Goldsmith A. D. ०-500. In: Magnus, B. (ed.), Roman Gold and the Development of the Early Germanic Kingdoms: Aspects of Technical, Socio-political, Socio-economic, Artistic and Intellectual Development, A.D. I-550. Symposium in Stockholm 1997. KVHAA Konferencer 5I, pp. 263-278. Stockholm: KVHAA.

Dodwell, C.R. I993. The Pictorial Arts of the West, 800-I200. Pelican History of Art Series. Cambridge: Yale University Press. 
Elbern, V.H. 1963. Der eucharistische Kelch im frühen Mittelalter. Zeitschrift des Deutschen Vereins für Kunstwissenschaft. Vol. I7 pp. I-76.

Elbern, V.H. I990. Zwischen England und Oberitalien: Die sog. insulare Kunstprovinz in Salzburg. Jahres- und Tagungsbericht der Görres-Gesellschaft. Vol. I989 pp. 96-II I.

Elbern, V.H. 1992. Auftraggeber und Künstler in der Goldschmiedekunst des frühen Mittelalters. In: Committenti e produzione artistico-letteraria nell'alto medioevo occidentale. Settimane di Studio des Centro italiano di studi sull'alto medioevo 39, 855-88I. Spoleto: Fondazione Centro Italiano di Studi Sull'Alto Medioevo.

Fern, C., Dickinson, T. \& Webster, L. (eds). 2019. The Staffordshire Hoard: An AngloSaxon Treasure. Reports of the Research Committee of the Society of Antiquaries of London 80. London: Society of Antiquaries.

Guichard, V. 20I2. Spiegel einer Gesellschaft im Wandel: Die spätkeltische Kunst. In: Die Welt der Kelten: Zentren der Macht, Kostbarkeiten der Kunst. Katalog zur Ausstellung vom I5. September 2012 bis I7. Februar 20I3 in Stuttgart, Hg. vom Archäologischen Landesmuseum Baden-Württemberg, dem Landesmuseum Württemberg und dem Landesamt für Denkmalpflege im Regierungspräsidium Stuttgart, pp. 400-409. Ostfildern: Thorbecke.

Hardt, M. 2004. Gold und Herrschaft: Die Schätze europäischer Könige und Fürsten im ersten Jahrtausend. Abhandlungen und Beiträge zur historischen Komparatistik, Hg. Michael Borgholte; Europa im Mittelalter 6. Berlin: Akademie Verlag.

Hardt, M. 20I 2. Edelmetallschmiede in erzählenden Quellen der Völkerwanderungszeit und des frühen Mittelalters. In: Pesch, A. \& Blankenfeldt, R. (eds), Goldsmith Mysteries: Archaeological, Pictorial and Documentary Evidence from the First Millennium AD in Northern Europe. Papers presented at a workshop organized by the Centre for Baltic and Scandinavian Archaeology (ZBSA), Schleswig, April 2oth and 2Ith, 20II. Schriften des Archäologischen Landesmuseums, Ergänzungsreihe Band 8, pp. 27I-278. Neumünster: Wachholtz.

Haseloff, G. I95 I. Der Tassilokelch. Münchner Beiträge zur Vor- und Frühgeschichte I. München: C.H. Beck'sche Verlagsbuchhandlung.

Haseloff, G. 1974. Der germanische Tierstil: Seine Anfänge und der Beitrag der Langobarden. Problemi attuali di scienza e di cultura. Accademia Nazionale dei Lincei, Quaderno N. I89-Atti del Convegno Internazionale sul tema: 'La civiltà dei Langobardi en Europa', pp. 36I-386.

Haseloff, G. I977. Zum Stand der Forschung zum Tassilokelch. In: Dimt, G. (ed.), Baiernzeit in Oberösterreich: Von Severin zu Tassilo. Ausstellung des oberösterreichischen Landesmuseums im Schlossmuseum zu Linz, pp. 22 I-236. Linz: Oberösterreichisches Landesmuseum.

Haseloff, G. I979a. Kunststile des frühen Mittelalters. Stuttgart: Württembergisches Landesmuseum.

Haseloff, G. I979b. Irland. In: Roth, H. (ed.), Kunst der Völkerwanderungszeit. Propyläen Kunstgeschichte, Supplement IV, pp. 223-236. Frankfurt am Main/Berlin/Wien: Propyläen.

Haseloff, G. I980. Die frühmittelalterlichen Chorschrankenfragmente aus Müstair. Helvetia Archaeologica. Vol. II pp. 2 I-39.

Haseloff, G. I98I. Die germanische Tierornamentik der Völkerwanderungszeit. Studien $z$ u Salin's Stil I. Vorgeschichtliche Forschungen I7, I-3. Berlin/New York: De Gruyter.

Haseloff, G. 1987. Insular Animal Styles with Special Reference to Irish Art in the Early Medieval Period. In: Ryan, M. (ed.), Ireland and Insular Art, A.D. 500-I200. Proceed- 
ings of a conference at University College, Cork, 3I October-3 November 1985, pp. 44-55. Dublin: Royal Irish Academy.

Hauck, K. 20II. Machttaten Odins: Die Chiffrenwelt der Brakteaten und die Methoden ihrer Auswertung. In: Heizmann, W. \& Axboe, M. (eds), Die Goldbrakteaten der Völkerwanderungszeit: Auswertung und Neufunde. Ergänzungsbände zum RGA 40, pp. I-6o. Berlin/New York: De Gruyter.

Hawkes, J. \& Mills, S. I999. Northumbria's Golden Age. Stroud: Sutton Publisher.

Henderson, G. 1987. From Durrow to Kells: The Insular Gospel-Books 650-800. New York: Thames and Hudson.

Herman, M. 20I7. The More Things Change, the More They Stay the Same: Decorative Continuity in Early Anglo-Saxon England. In: Bintley, M.D.J., Locker, M., Symons, V. \& Wellesley, M. (eds), Stasis in the Medieval West? Questioning Change and Continuity, pp. 47-68. New York: Springer.

Høilund Nielsen, K. I998. Animal Style: A Symbol of Might and Myth. Acta Archaeologica. Vol. 69 pp. I-52.

Høilund Nielsen, K. \& Kristoffersen, S. 2002. Germansk dyrestil (Salin I-III): Et historisk perspektiv. Hikuin. Vol. 29 pp. I5-74.

Holländer, H. 198г. Kunst des Frühen Mittelalters. Belser Stilgeschichte. Herrschingen: Reclam.

Holmqvist, W. I980. Guldhalskragarna. Stockholm: LTs förlag.

IK = Ikonographischer Katalog 1985-I989: Karl Hauck et al., Die Goldbrakteaten der Völkerwanderungszeit. Ikonographischer Katalog. Münstersche Mittelalter-Schriften 24, I,I bis 3,2. München: Wilhelm Fink Verlag.

Karlsson, L. I983. Nordisk Form, om djurornamentik. The Museum of National Antiquities, Stockholm, Studies 3. Stockholm: Statens historiska museum.

Kendrick, T.D. 1934. Style in Early Anglo-Saxon Ornament. Ipek. Vol. 9 pp. 66-76.

Kendrick, T.D. I938: Anglo-Saxon Art to AD 900. London: Methuen.

Lamm, J.P. I99I. Zur Taxonomie der schwedischen Goldhalskragen der Völkerwanderungszeit. Fornvännen. Vol. 86 pp. I53-167.

McDermott, M. I955: The Kells Crosier. Archaeologia. Vol. 96 pp. 59-II3.

Mütherich, F. I999. Die Erneuerung der Buchmalerei am Hof Karls des Großen. In: Stiegemann, Ch. \& Wemhoff, M. (eds), 799. Kunst und Kultur der Karolingerzeit: Karl der Große und Papst Leo III. in Paderborn. Katalog zur Ausstellung vom 23. Juli bis I. November 1999. Bd. 3, pp. 560-609. Paderborn: Philipp von Zabern.

Mütherich, F. \& Gaehrde, J.E. 1976. Karolingische Buchmalerei. München: Prestel.

Ørsnes, M. I966. Form og stil i Sydskandinaviens yngre germanske jernalder. Nationalmuseets skrifter, Arkæologisk-historisk række i . København: Nationalmuseet/Gyldendal.

Pächt, O. 1989. Buchmalerei des Mittelalters: Eine Einführung. München: Prestel-Verlag.

Paulsen, P. I953. Koptische und irische Kunst und ihre Ausstrahlungen auf altgermanische Kulturen. Tribus: Jahrbuch des Linden-Museums Stuttgart. Vol. 2/3 pp. I49-187.

Paulsen, P. 1967. Alamannische Adelsgräber von Niederstotzingen. Veröff. des staatl. Amtes f. Denkmalpflege Stuttgart, Reihe A: Vor. und Frühgesch. Heft I2/I. Stuttgart: Müller \& Gräff.

Pesch, A. 2007. Thema und Variation: Die Goldbrakteaten der Völkerwanderungszeit. Ergänzungsbände zum RGA 36. Berlin/New York: De Gruyter. 
Pesch, A. 20I2. Fallstricke und Glatteis: Die germanische Tierornamentik In: Beck, H., Geuenich, D. \& Steuer, H. (eds), Altertumskunde-Altertumswissenschaft-Kulturwissenschaft: Erträge und Perspektiven nach 40 Jahren Reallexikon der germanischen $\mathrm{Al}$ tertumskunde. Ergänzungsbände zum Reallexikon der germanischen Altertumskunde 77, pp. 633-687. Berlin/Boston: De Gruyter.

Pesch, A. 20I5. Die Kraft der Tiere: Völkerwanderungszeitliche Goldhalskragen und die Grundsätze germanischer Kunst. Unter Mitarbeit von Jan Peder Lamm, Maiken Fecht und Barbara Armbruster. Kataloge Vor- und Frühgeschichtlicher Altertümer 47, zugleich Schriften des archäologischen Landesmuseums, Monographien I2. Mainz: Verlag RGZM.

Pesch, A. 20I9. Die Tierfiguren auf dem Kelch: Tassilos Glasperlenspiel. In: Wamers, E. (ed.), Der Tassilo-Liutpirc-Kelch aus dem Stift Kremsmünster: Geschichte Archäologie Kunst, Schriften des Archäologischen Museums Frankfurt 32, pp. 32 I-335. Regensburg: Schnell \& Steiner.

Pesch, A. \& Blankenfeldt, R. (eds). 2012. Goldsmith Mysteries: Archaeological, Pictorial and Documentary Evidence from the First Millennium AD in Northern Europe. Papers presented at a workshop organized by the Centre for Baltic and Scandinavian Archaeology (ZBSA), Schleswig, April 2oth and 2Ith, 20II. Schriften des Archäologischen Landesmuseums, Ergänzungsreihe Band 8. Neumünster: Wachholtz.

Prochno, R. 2005. Der Tassilokelch: Anmerkungen zur Forschungsgeschichte. In: Kolmer, L. \& Rohr, C. (eds), Tassilo III. von Bayern: Großmacht und Ohnmacht im 8. Jahrbundert, pp. I55-I74. Regensburg: Verlag Friedrich Pustet.

Quast, D. 20I 2. Das merowingerzeitliche Reliquienkästchen aus Ennabeuren: Eine Studie $z u$ den frühmittelalterlichen Reisereliquiaren und Chrismalia. Mit Beiträgen von Jean Berger und Roland Deigendesch. Kataloge Vor- und Frühgeschichtlicher Altertümer 43. Mainz: Verlag RGZM.

Roth, H. 1986. Kunst und Handwerk im frühen Mittelalter: Archäologische Zeugnisse von Childerich I. bis zu Karl dem Großen. Stuttgart: Theiss.

Roth, H. 1998. Germanen, Germania, Germanische Altertumskunde, C. Kunst. In: Reallexikon der Germanischen Altertumskunde. Vol. II pp. 356-368.

Roth, U. 1987. Early Insular Manuscripts: Ornament and Archaeology. With special Reference to the Dating of the Book of Durrow. In: Ryan, M. (ed.), Ireland and Insular Art, A.D. 500-I 200. Proceedings of a conference at University College, Cork, 3 I October-3 November, pp. 23-29. Dublin: Royal Irish Academy.

Roth, U. 2002. Insulare Tierstile: Entwicklungsgeschichtliche Aspekte. Hikuin. Vol. 2002 pp. 219-242.

Roth-Rubi, K. 20I r. Das Antependium in der Klosterkirche St. Johann von Müstair. In: Amt für Kultur, Archäologischer Dienst Graubünden Chur (ed.). Vom Steinbeil zur Flintenkugel: Festschrift zur Pensionierung von Jürg Rageth, pp. 67-77. Chur: Amt für Kultur.

Roth-Rubi, K. 20I9. Frühmittelalterliche Skulptur in Rätien und den Chiemsee-Klöstern: Bemerkungen zu historischen Aspekten. In: Wamers, E. (ed) 20I9, Der Tassilo-Liutpirc-Kelch aus dem Stift Kremsmünster: Geschichte Archäologie Kunst, Schriften des Archäologischen Museums Frankfurt 32, 297-3I5. Regensburg: Schnell \& Steiner.

Ryan, M. 2019. Insular Chalices and the Tassilo-Liutpirc Chalice. In: Wamers, E. (ed.), Der Tassilo-Liutpirc-Kelch aus dem Stift Kremsmünster: Geschichte Archäologie Kunst. Schriften des Archäologischen Museums Frankfurt 32, pp. 287-296. Regensburg: Schnell \& Steiner. 
Scull, C. 2015. Chronology, Burial and Conversion: The Case of England in the 7 th Century. In: Ruhmann, C. \& Brieske, V. (eds), Dying Gods: Religious Beliefs in Northern and Eastern Europe in the Time of Christianisation. Neue Studien zur Sachsenforschung 5, pp. 73-83. Hannover: Konrad Theiss Verlag.

Scull, C., Minter, F. \& Plouviez, J. 20I6. Social and Economic Complexity in Early Medieval England: A Central Place Complex of the East Anglian Kingdom at Rendlesham, Suffolk. Antiquity. Vol. 90(354) pp. I594-I6r2.

Salin, B. 1904. Die altgermanische Thierornamentik. Typologische Studie über germanische Metallgegenstände aus dem IV-IX Jahrhundert, nebst einer Studie über irische Ornamentik. Aus dem schwedischen Manuskript übersetzt von Johanna Mestorf. Stockholm: K.L. Beckmans Buchdruckerei, in Kommission bei A. Asher, Berlin.

Stein, F. I967. Adelsgräber des achten Jahrhunderts in Deutschland. Text, Tafeln. Germanische Denkmäler der Völkerwanderungszeit Serie A, 9. Berlin: De Gruyter.

Stiegemann, C., Kroker, M. \& Walter, W. (eds). 2013. Credo. Christianisierung Europas im Mittelalter. Katalog zur Paderborner Ausstellung 26. Juli bis 3. November 20I3. Bd. I Essays, Bd. 2 Katalog. Petersberg: Imhof.

Stolpe, H. \& Arne, T.J. I9г2. Gravfältet vid Vendel. Kungl. Vitterhets historie och antikvitetsakademien. Monografier 3. Stockholm: Kungliga Vitterhets-, Historie- och Antikvitetsakademien.

Swarzenski, G. I9I3. Die Salzburger Malerei von den ersten Anfüngen bis zur Blütezeit des romanischen Stils. Studien zur Geschichte der deutschen Malerei und Handschriftenkunde des Mittelalters, Textband. Leipzig: Anton Hiersemann Verlag.

Trætteberg, H., Moltke, E. \& Lindeberg, I. 1982. Triquetra. Kulturhistorisk Leksikon for Nordisk Middelalder fra Vikingetid til Reformationstid. Vol. 18, 634-636.

Vierck, H. I974. Werke des Eligius. In: Kossack, G. \& Ulbert, G. (eds), Studien zur vor-und frühgeschichtlichen Archäologie. Festschrift für Joachim Werner zum 65. Geburtstag. Münchener Beiträge zur Vor- und Frühgeschichte, Ergänzungsband I, pp. 309-38I. München: C.H. Beck.

Wamers, E. I991. Pyxides imaginatae: Zur Ikonographie und Funktion karolingischer Silberbecher. Germania. Vol. 69 pp. 97-I52.

Wamers, E. I993. Insular Art in Carolingian Europe: The Reception of Old Ideas in a New Empire. In: Spearman, R.M. \& Higgitt, J. (eds), The Age of Migrating Ideas: Early Medieval Art in Northern Britain and Irland, pp. 35-44. Edinburgh/Gloucestershire/ Dover (USA): Sutton Pub Ltd.

Wamers, E. I999. Zwischen Salzburg und Oseberg: Zu Ursprung und Ikonographie des nordischen Greiftierstils. In: Freeden, U. von, Koch, U. \& Wieczorek, A. (eds), Völker an Nord- und Ostsee und die Franken: Akten des 48. Saschensymposiums, pp. 195228. Bonn: Dr. Rudolf Habelt GmhH.

Wamers, E. 2005. Tassilo-Kelch. In: Reallexikon der Germanischen Altertumskunde. Vol. 30 pp. 293-294.

Wamers, E. 2008a. Glaubensboten: 'Aristokratische' Kunststile des 8. bis Io. Jahrhunderts n. Chr. In: Eggenstein, G. (ed.), Eine Welt in Bewegung: Unterwegs zu Zentren des frühen Mittelalters. Begleitbuch zur Gemeinschaftsausstellung Paderborn Schloss Neuhaus, Mainfränkisches Museum Würzburg - Festung Marienburg, pp. 3750. München: Deutscher Kunstverlag.

Wamers, E. 2008b. Salins Stil II auf christlichen Gegenständen: Zur Ikonographie merowingerzeitlicher Kunst im 7. Jahrhundert. Zeitschrift für Archäologie des Mittelalters. Vol. $36 \mathrm{pp} .33-72$. 
Wamers, E. 20I3. Tassilo III. Von Baiern oder Karl der Große? Zur Ikonographie und Programmatik des sogenannten Tassilokelch-Stils. In: Sennhauser, H.-R. (ed.), unter Mitarbeit von Katrin Roth-Rubi und Eckart Kühne, Wandel und Konstanz zwischen Bodensee und Lombardei zur Zeit Karls des Grossen. Kloster St. Johann in Müstair und Churrätien. Tagung I3.-I6. Juni 20 I 2 in Müstair. Acta Müstair, Kloster St. Johann 3, pp. 427-448. Zürich: Vdf Hochschulverlag.

Wamers, E. 20I5. Locus amoenus. 'Becher I9' im Kontext der kontinentalen Kunst des 8. und 9. Jahrhunderts. In: Daim, F., Gschwantler, K., Plattner, G. \& Stadler, P. (eds), Der Goldschatz von Sennicolai mare: RGZM Tagungen Mainz 25, pp. 7 I-I I9. Mainz: Verlag RGZM.

Wamers, E. (ed.). 2019. Der Tassilo-Liutpirc-Kelch aus dem Stift Kremsmünster: Geschichte Archäologie Kunst. Schriften des Archäologischen Museums Frankfurt 32. Regensburg: Schnell \& Steiner.

Wamers, E. 20I9a. The Tassilo-Liutpirc Chalice at Kremsmünster Monastery: A synopsis. In: Wamers, E. (ed.), Der Tassilo-Liutpirc-Kelch aus dem Stift Kremsmünster: Geschichte Archäologie Kunst. Schriften des Archäologischen Museums Frankfurt 32, pp. 494-496. Regensburg: Schnell \& Steiner.

Wamers, E. 20I9b. Cum tesauris ac familia: Zur Schatzkunst und Hofschule Tassilos III. In: Wamers, E. (ed.), Der Tassilo-Liutpirc-Kelch aus dem Stift Kremsmünster: Geschichte Archäologie Kunst. Schriften des Archäologischen Museums Frankfurt 32, pp. 377-450. Regensburg: Schnell und Steiner.

Wamers, E. 20I9c. Urbs caelestris: Die Bildstruktur des Tassilo-Liudpirc-Kelches. In: Wamers, E. (ed.), Der Tassilo-Liutpirc-Kelch aus dem Stift Kremsmünster: Geschichte Archäologie Kunst. Schriften des Archäologischen Museums Frankfurt 32, pp. 45 I-490. Regensburg: Schnell \& Steiner.

Wamers, E., Reichert, H. \& Beck, H. 200I. Löwe und Löwendarstellungen. Reallexikon der Germanischen Altertumskunde. Vol. I8 pp. 556-566.

Webster, L. 20I 2: Anglo-Saxon Art. London: The British Museum.

Werner, J. 1959. Frühkarolingische Silberohrringe von Rastede (Oldenburg): Beiträge zur Tierornamentik des Tassilokelches und verwandter Denkmäler. Germania. Vol. 37 pp. I79-I92.

Werner, J. 1966. Zum Cundpald-Kelch von Petöháza: Mit Beiträgen von H. Fromm und B. Bischoff. Jahrbuch des Römisch Germanischen Zentralmuseums Mainz. Vol. I3 pp. $265-278$.

Wilson, D.M. 1960. The Fejø Cup. Acta Archaeologica. Vol. 6I pp. I47-I73.

Wilson, D.M. I986. Durrow. In: Reallexikon der Germanischen Altertumskunde. Vol. 6 pp. 295-296.

Wintz, P.K. 20I4. Tassilokelch. In: van den Brink, P. \& Ayoogh, S. (eds), Karl der Große - Charlemagne. Karls Kunst. Katalog der Sonderausstellung Karls Kunst vom 20. Juni bis 2r. September 20I 4 im Centre Charlemagne, Aachen, pp. I96-I97. Dresden: Sandstein Kommunikation.

Zarnecki, G. I990. Germanic Animal Motifs in Romanesque Sculpture. Artibus et historiae: Rivista internazionale di arti visive e cinema. Vol. II(22) pp. I89-203.

Žvanut, K. 2002. The Tassilo Chalice Style: Problems of Interpretation and Definition. Hortus artium medievalium. Vol. 8 pp. 273-288. 